\title{
NASA/DoD Aerospace Knowledge Diffusion Research Project
}

NASA Technical Memorandum 110238

\section{Report Number 45}

The Technical Communications Practices of U.S. Aerospace Engineers and Scientists: Results of the Phase 3 U.S. Aerospace Engineering Educators Survey

Thomas E. Pinelli

NASA Langley Research Center

Hampton, Virginia

Rebecca O. Barclay

Knowledge Transfer International

Portsmouth, Virginia

John M. Kennedy

Indiana University

Bloomington, Indiana

July 1996
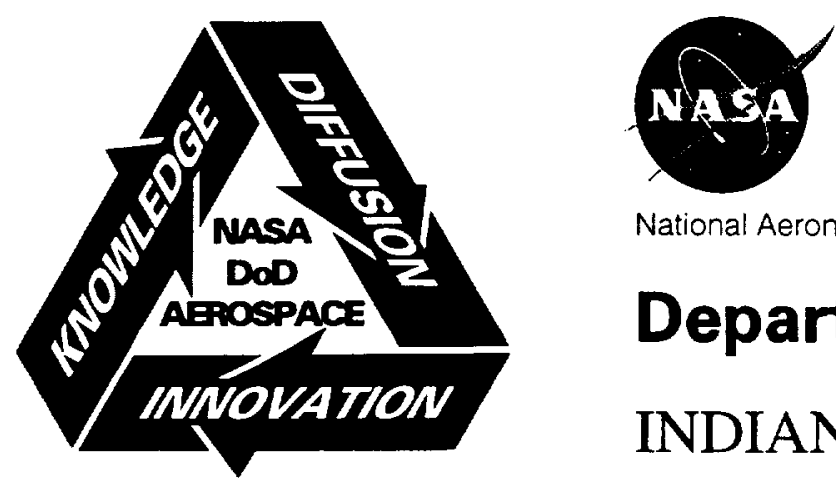

National Aeronautics and Space Administration

Department of Defense INDIANA UNIVERSITY 



\title{
THE TECHNICAL COMMUNICATIONS PRACTICES OF U.S. AEROSPACE ENGINEERS AND SCIENTISTS: RESULTS OF THE PHASE 3 U.S. AEROSPACE ENGINEERING EDUCATORS SURVEY
}

\author{
Thomas E. Pinelli, Rebecca O. Barclay, and John M. Kennedy
}

\begin{abstract}
The U.S. government technical report is a primary means by which the results of federally funded research and development (R\&D) are transferred to the U.S. aerospace industry. However, little is known about this information product in terms of its actual use, importance, and value in the transfer of federally funded R\&D. Little is also known about the intermediary-based system that is used to transfer the results of federally funded R\&D to the U.S. aerospace industry. To help establish a body of knowledge, the U.S. government technical report is being investigated as part of the NASA/DoD Aerospace Knowledge Diffusion Research Project. In this report, we summarize the literature on technical reports, present a model that depicts the transfer of federally funded aerospace R\&D via the U.S. government technical report, and present the results of research that investigated aerospace knowledge diffusion vis-à-vis the technical communication practices of U.S. aerospace engineers and scientists who were members of the American Institute of Aeronautics and Astronautics (AIAA) and identified themselves as educators.
\end{abstract}

\section{INTRODUCTION}

NASA and the DoD maintain scientific and technical information (STI) systems for acquiring, processing, announcing, publishing, and transferring the results of governmentperformed and government-sponsored research. Within both the NASA and DoD STI systems, the U.S. government technical report is considered a primary mechanism for transferring the results of this research to the U.S. aerospace community. However, McClure (1988) concludes that we actually know little about the role, importance, and impact of the technical report in the transfer of federally funded $R \& D$ because little empirical information about this product is available.

We are examining the system(s) used to diffuse the results of federally funded aerospace R\&D as part of the NASA/DoD Aerospace Knowledge Diffusion Research Project. This project investigates, among other things, the information-seeking behavior of U.S. aerospace engineers and scientists, the factors that influence the use of STI, and the role played by U.S. government technical reports in the diffusion of federally funded aerospace STI (Pinelli, Kennedy, and Barclay, 1991; Pinelli, Kennedy, Barclay, and White, 1991). The results of this investigation could (1) advance the development of practical theory, (2) contribute to the design and development of aerospace information systems, and (3) have practical implications for transferring the results of federally funded aerospace R\&D to the U.S. aerospace community. The project fact sheet is Appendix A. 
In this report, we summarize the literature on technical reports, provide a model that depicts the transfer of federally funded aerospace R\&D through the U.S. government technical report, and present the results of the Phase 3 Aerospace Engineering Educators mail survey. We summarize the findings of the Phase 3 mail survey in terms of the technical communication practices of U.S. aerospace engineers and scientists who were members of the American Institute of Aeronautics and Astronautics (AlAA) and were identified as educators.

\section{THE U.S. GOVERNMENT TECHNICAL REPORT}

Although they have the potential for increasing technological innovation, productivity, and economic competitiveness, U.S. government technical reports may not be utilized because of limitations in the existing transfer mechanism. According to Ballard, et al., (1986), the current system "virtually guarantees that much of the Federal investment in creating STI will not be paid back in terms of tangible products and innovations." They further state that "a more active and coordinated role in STI transfer is needed at the Federal level if technical reports are to be better utilized."

\section{Characteristics of Technical Reports}

The definition of the technical report varies because the report serves different roles in communication within and between organizations. The technical report has been defined etymologically, according to report content and method (U.S. Department of Defense, 1964); behaviorally, according to the influence on the reader (Ronco, et al., 1964); and rhetorically, according to the function of the report within a system for communicating STI (Mathes and Stevenson, 1976). The boundaries of technical report literature are difficult to establish because of wide variations in the content, purpose, and audience being addressed. The nature of the report -- whether it is informative, analytical, or assertive -- contributes to the difficulty.

Fry (1953) points out that technical reports are heterogenous, appearing in many shapes, sizes, layouts, and bindings. According to Smith (1981), "Their formats vary; they might be brief (two pages) or lengthy (500 pages). They appear as microfiche, computer printouts or vugraphs, and often they are loose leaf (with periodic changes that need to be inserted) or have a paper cover, and often contain foldouts. They slump on the shelf, their staples or prong fasteners snag other documents on the shelf, and they are not neat."

Technical reports may exhibit some or all of the following characteristics (Gibb and Phillips, 1979; Subramanyam, 1981):

- Publication is not through the publishing trade.

- Readership/audience is usually limited. 
- Distribution may be limited or restricted.

- Content may include statistical data, catalogs, directions, design criteria, conference papers and proceedings, literature reviews, or bibliographies.

- Publication may involve a variety of printing and binding methods.

The SATCOM report (National Academy of Sciences - National Academy of Engineering, 1969) lists the following characteristics of the technical report:

- It is written for an individual or organization that has the right to require such reports.

- It is basically a stewardship report to some agency that has funded the research being reported.

- It permits prompt dissemination of data results on a typically flexible distribution basis.

- It can convey the total research story, including exhaustive exposition, detailed tables, ample illustrations, and full discussion of unsuccessful approaches.

\section{History and Growth of the U.S. Government Technical Report}

The development of the [U.S. government] technical report as a major means of communicating the results of R\&D, according to Godfrey and Redman (1973), dates back to 1941 and the establishment of the U.S. Office of Scientific Research and Development (OSRD). Further, the growth of the U.S. government technical report coincides with the expanding role of the Federal government in science and technology during the post World War II era. However, U.S. government technical reports have existed for several decades. The Bureau of Mines Reports of Investigation (Redman, 1965/66), the Professional Papers of the United States Geological Survey, and the Technological Papers of the National Bureau of Standards (Auger, 1975) are early examples of U.S. government technical reports. Perhaps the first U.S. government publications officially created to document the results of federally funded (U.S.) R\&D were the technical reports first published by the National Advisory Committee for Aeronautics (NACA) in 1917.

Auger (1975) states that "the history of technical report literature in the U.S. coincides almost entirely with the development of aeronautics, the aviation industry, and the creation of the NACA, which issued its first report in 1917." In her study, Information Transfer in Engineering, Shuchman (1981) reports that $75 \%$ of the engineers she surveyed used technical reports; that technical reports were important to engineers doing applied work; and that aerospace engineers, more than any other group of engineers, referred to technical reports. However, in many of these studies, including Shuchman's, it is often unclear whether U.S. government technical reports, non-U.S. government technical reports, or both are included (Pinelli, 1991a). 
The U.S. government technical report is a primary means by which the results of federally funded $R \& D$ are made available to the scientific community and are added to the literature of science and technology (President's Special Assistant for Science and Technology, 1962). McClure (1988) points out that "although the [U.S.] government technical report has been variously reviewed, compared, and contrasted, there is no real knowledge base regarding the role, production, use, and importance [of this information product] in terms of accomplishing this task." Our analysis of the literature supports the following conclusions reached by McClure:

- The body of available knowledge is simply inadequate and noncomparable to determine the role that the U.S. government technical report plays in transferring the results of federally funded R\&D.

- Further, most of the available knowledge is largely anecdotal, limited in scope and dated, and unfocused in the sense that it lacks a conceptual framework.

- The available knowledge does not lend itself to developing "normalized" answers to questions regarding U.S. government technical reports.

\section{THE TRANSFER OF FEDERALLY FUNDED AEROSPACE R\&D AND THE U.S. GOVERNMENT TECHNICAL REPORT}

Three paradigms -- appropriability, dissemination, and diffusion -- have dominated the transfer of federally funded (U.S.) R\&D (Ballard, et al., 1989; Williams and Gibson, 1990). Whereas variations of them have been tried within different agencies, overall Federal (U.S.) STI transfer activities continue to be driven by a "supply-side," dissemination model.

\section{The Appropriability Model}

The appropriability model emphasizes the production of knowledge by the Federal government that would not otherwise be produced by the private sector and competitive market pressures to promote the use of that knowledge. This model emphasizes the production of basic research as the driving force behind technological development and economic growth and assumes that the Federal provision of R\&D will be rapidly assimilated by the private sector. Deliberate transfer mechanisms and intervention by information intermediaries are viewed as unnecessary. Appropriability stresses the supply (production) of knowledge in sufficient quantity to attract potential users. Good technologies, according to this model, sell themselves and offer clear policy recommendations regarding Federal priorities for improving technological development and economic growth. This model incorrectly assumes that the results of federally funded R\&D will be acquired and used by the private sector, ignores the fact that most basic research is irrelevant to technological innovation, and dismisses the process of technological innovation within the firm. 


\section{The Dissemination Model}

The dissemination model emphasizes the need to transfer information to potential users and embraces the belief that the production of quality knowledge is not sufficient to ensure its fullest use. Linkage mechanisms, such as information intermediaries, are needed to identify useful knowledge and to transfer it to potential users. This model assumes that if these mechanisms are available to link potential users with knowledge producers, then better opportunities exist for users to determine what knowledge is available, acquire it, and apply it to their needs. The strength of this model rests on the recognition that STI transfer and use are critical elements of the process of technological innovation. Its weakness lies in the fact that it is passive, for it does not take users into consideration except when they enter the system and request assistance. The dissemination model employs one-way, source-to-user transfer procedures that are seldom responsive in the user context. User requirements are seldom known or considered in the design of information products and services.

\section{The Knowledge Diffusion Model}

The knowledge diffusion model is grounded in theory and practice associated with the diffusion of innovation and planned change research and the clinical models of social research and mental health. Knowledge diffusion emphasizes "active" intervention as opposed to dissemination and access; stresses intervention and reliance on interpersonal communications as a means of identifying and removing interpersonal barriers between users and producers; and assumes that knowledge production, transfer, and use are equally important components of the $\mathrm{R} \& \mathrm{D}$ process. This approach also emphasizes the link between producers, transfer agents, and users and seeks to develop user-oriented mechanisms (e.g., products and services) specifically tailored to the needs and circumstances of the user. It makes the assumption that the results of federally funded $R \& D$ will be under utilized unless they are relevant to users and ongoing relationships are developed among users and producers. The problem with the knowledge diffusion model is that (1) it requires a large Federal role and presence and (2) it runs contrary to the dominant assumptions of established Federal R\&D policy. Although U.S. technology policy relies on a "dissemination-oriented" approach to STI transfer, other industrialized nations, such as Germany and Japan, are adopting "diffusion-oriented" policies which increase the power to absorb and employ new technologies productively (Branscomb, 1992; Branscomb, 1991).

\section{The Transfer of (U.S.) Federally-Funded Aerospace R\&D}

A model depicting the transfer of federally funded aerospace R\&D through the U.S. government technical report appears in figure 1 . The model is composed of two parts -- the informal that relies on collegial contacts and the formal that relies on surrogates, information producers, and information intermediaries to complete the "producer to user" transfer process.

When U.S. government (i.e., NASA) technical reports are published, the initial or primary distribution is made to libraries and technical information centers. Copies are sent to surrogates 


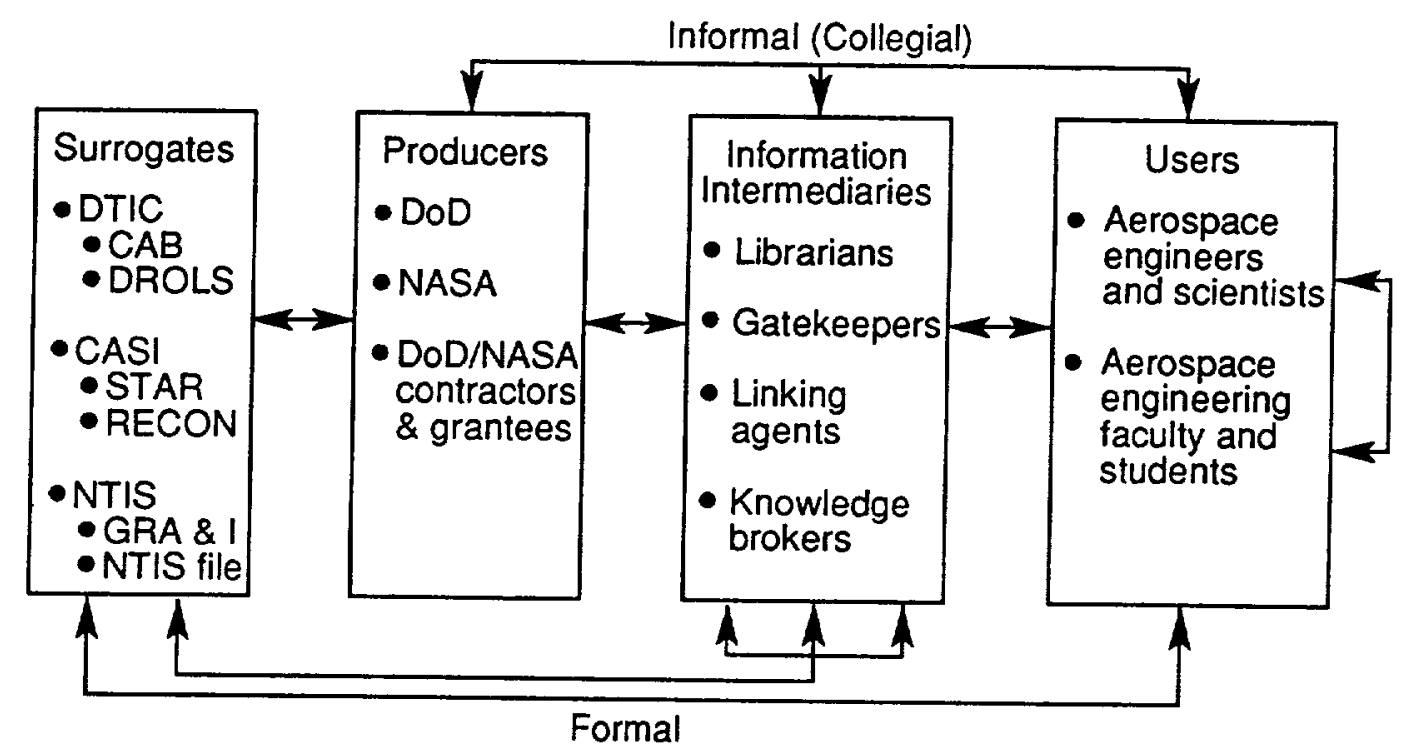

Figure 1. The U.S. Government Technical Report in a Model Depicting the Dissemination of Federally Funded Aerospace R\&D.

for secondary and subsequent distribution. A limited number of copies are set aside to be used by the author for the "scientist-to-scientist" exchange of information at the collegial level.

Surrogates serve as technical report repositories or clearinghouses for the producers and include the Defense Technical Information Center (DTIC), the NASA Center for Aero Space Information (CASI), and the National Technical Information Service (NTIS). These surrogates have created a variety of technical report announcement joumals such as $C A B$ (Current Awareness Bibliographies), STAR (Scientific and Technical Aerospace Reports), and GRA\&I (Government Reports Announcement and Index) and computerized retrieval systems such as DROLS (Defense RDT\&E Online System), RECON (REsearch CONnection), and NTIS On-line that permit online access to technical report data bases. Information intermediaries are, in large part, librarians and technical information specialists in academia, government, and industry. Those representing the producers serve as what McGowan and Loveless (1981) describe as "knowledge brokers" or "linking agents." Information intermediaries connected with users act, according to Allen (1977), as "technological entrepreneurs" or "gatekeepers." The more "active" the intermediary, the more effective the transfer process becomes (Goldhor and Lund, 1983). Active intermediaries move information from the producer to the user, often utilizing interpersonal (i.e., face-to-face) communication in the process. Passive information intermediaries, on the other hand, "simply array information for the taking, relying on the initiative of the user to request or search out the information that may be needed" (Eveland, 1987).

The overall problem with the total Federal STI system is that "the present system for transferring the results of federally funded STI is passive, fragmented, and unfocused;" effective 
knowledge transfer is hindered by the fact that the Federal government "has no coherent or systematically designed approach to transferring the results of federally funded R\&D to the user" (Ballard, et al., 1986). In their study of issues and options in Federal STI, Bikson and her colleagues (1984) found that many of the interviewees believed "dissemination activities were afterthoughts, undertaken without serious commitment by Federal agencies whose primary concerns were with [knowledge] production and not with knowledge transfer;" therefore, "much of what has been learned about [STI] and knowledge transfer has not been incorporated into federally supported information transfer activities."

Problematic to the informal part of the system is that knowledge users can learn from collegial contacts only what those contacts happen to know. Ample evidence supports the claim that no one researcher can know about or keep up with all the research in his/her area(s) of interest. Like other members of the scientific community, aerospace engineers and scientists are faced with the problem of too much information to know about, to keep up with, and to screen. Further, information is becoming more interdisciplinary in nature and more international in scope.

Two problems exist with the formal part of the system. First, the formal part of the system employs one-way, source-to-user transmission. The problem with this kind of transmission is that such formal one-way, "supply side" transfer procedures do not seem to be responsive to the user context (Bikson, et al., 1984). Rather, these efforts appear to start with an information system into which the users' requirements are retrofit (Adam, 1975). The consensus of the findings from the empirical research is that interactive, two-way communications are required for effective information transfer (Bikson, et al., 1984).

Second, the formal part relies heavily on information intermediaries to complete the knowledge transfer process. However, a strong methodological base for measuring or assessing the effectiveness of the information intermediary is lacking (Beyer and Trice, 1982). In addition, empirical data on the effectiveness of information intermediaries and the role(s) they play in knowledge transfer are sparse and inconclusive. The impact of information intermediaries is likely to be strongly conditional and limited to a specific institutional context.

According to Roberts and Frohman (1978), most Federal approaches to knowledge utilization have been ineffective in stimulating the diffusion of technological innovation. They claim that the numerous Federal STI programs are "highest in frequency and expense yet lowest in impact" and that Federal "information dissemination activities have led to little documented knowledge utilization." Roberts and Frohman also note that "governmental programs start to encourage utilization of knowledge only after the $R \& D$ results have been generated" rather than during the idea development phase of the innovation process. David (1986), Mowery (1983), and Mowery and Rosenberg (1979) conclude that successful [Federal] technological innovation rests more with the transfer and utilization of knowledge than with its production. 


\section{THE INFORMATION-SEEKING BEHAVIOR OF ENGINEERS}

The information-seeking behavior of engineers and scientists has been variously studied by information and social scientists, the earliest studies having been undertaken in the late 1960s (Pinelli, 1991b). The results of these studies have not accumulated to form a significant body of knowledge that can be used to develop a general theory regarding the information-seeking behavior of engineers and scientists. The difficulty in applying the results of these studies has been attributed to the lack of a unifying theory, a standardized methodology, and the common definitions (Rohde, 1986).

Despite the fact that numerous "information use" studies have been conducted, the information-seeking behavior of engineers and information use in engineering are neither broadly known nor well understood. There are a number of reasons (Berul, et al., 1965): (1) many of the studies were conducted for narrow or specific purposes in unique environments such as experimental laboratories; (2) many, if not most, of them focused on scientists exclusively or engineers working in a research environment; (3) few studies have concentrated on engineers, especially engineers working in manufacturing and production; (4) from an information use standpoint, some engineering disciplines have yet to be studied; (5) most of the studies have concentrated on the users' use of information in terms of a library and/or specific information packages such as professional journals rather than how users produce, transfer, and use information; and (6) many of the studies, as previously stated, were not methodologically sophisticated and few included testable hypotheses or valid procedures for testing the study's hypotheses.

Further, we know very little about the diffusion of knowledge in specific communities such as aerospace. In the past 25 years, few studies have been devoted to understanding the information environment in which aerospace engineers and scientists work, the information-seeking behavior of aerospace engineers and scientists, and the factors that influence the use of federally funded aerospace STI. Presumably, the results of such studies would have implications for current and future aerospace STI systems and for making decisions regarding the transfer and use of federally funded aerospace STI.

\section{RESULTS OF THE PHASE 3 U.S. AEROSPACE ENGINEERING EDUCATORS MAIL SURVEY}

This research was conducted as a Phase 3 activity of the NASA/DoD Aerospace Knowledge Diffusion Research Project. Survey participants consisted of U.S. aerospace engineers and scientists who were members of the American Institute of Aeronautics and Astronautics (AIAA) and identified themselves as educators. The survey instrument appears as Appendix B.

\section{The Survey}

The questionnaire used in this study was jointly prepared by the project team and representatives from the Indiana University Center for Survey Research (CSR). The survey was 
pretested on a group of aerospace engineers and scientists across the country. The Indiana University staff prepared an envelope for each individual that contained an 11-page questionnaire and the cover letter. A random sample of 500 AIAA members who identified themselves as educators were selected from the group. The envelopes were packaged and mailed to the NASA Langley Research Center (LaRC) on February 9, 1996, for mailing. The envelopes were mailed from NASA LaRC on February 13, 1996.

Between February 13 and April 16, 1996, 324 usable questionnaires were returned. Thirtyseven questionnaires were returned as unusable because (1) the recipient was not an educator, (2) the survey was not applicable to them, or (3) the recipient was too busy to participate in the study. The adjusted completion rate for the survey was $72.2 \%$.

\section{Data Collection and Analysis}

A variation of Flanagan's (1954) critical incident technique was used to guide data collection. According to Lancaster (1978), the theory behind the critical incident technique is that it is much easier for people to recall accurately what they did on a specific occurrence or occasion than it is to remember what they do in general. Respondents were asked to categorize the most important job-related projects, task, or problem they had worked on in the past 6 months. The categories included (1) research, (2) design, (3) development, (4) manufacturing, (5) production, (6) quality assurance/control, (7) computer applications, (8) management, and (9) other.

Respondents were also asked to rate the amount of technical uncertainty and complexity they faced when they started their most important project, task, or problem. Technical uncertainty and complexity were measured on 5-point scales $(1.0=$ little uncertainty; $5.0=$ great uncertainty; 1.0 $=$ little complexity, 5.0 = great complexity). Survey participants were also asked to indicate whether they worked alone or with others in completing/solving the most important job-related project, task, or problem they had worked on in the past 6 months.

Technical uncertainty, complexity, and the importance of federally funded aerospace R\&D were measured using ordinal scales. Hours spent communicating and the number of journal articles, conference-meeting papers, and U.S. government technical reports used were measured on an interval scale. Use of formal information sources and federally funded aerospace R\&D were measured using a nominal scale. Data analysis was based on 324 responses, the total number of usable surveys received by the established cut-off date. 


\section{DESCRIPTIVE FINDINGS}

Survey demographics for the 324 respondents appear in table 1. The following "composite" participant profile was developed for the respondents: works in academia (100\%), has a doctorate (92.0\%), has an average of 22 years of aerospace work experience, was educated as and works as an engineer $(63.5 \%)$, and is male $(95.0 \%)$.

\section{Project, Task, Problem}

Survey participants were asked to categorize the most important job-related project, task, or problem they had worked on in the past 6 months. The categories and responses are listed in table 2. A majority of the job-related projects, tasks, and problems (74.8\%) were categorized as research. About $12.1 \%$ and $6.5 \%$ of the job-related projects, tasks, and problems were categorized as other and management, respectively. Most respondents (75.6\%) worked with others (did not work alone) in completing their most important job-related project, task, or problem.

Number of Groups and Group Size. On average, respondents worked with 2.6 groups; each group contained an average of 4.4 members (table 2). A majority of respondents (65.0\%) performed engineering duties while working on their most important job-related project, task, or problem. About $8.4 \%$ performed management duties.

Project, Task, Problem Complexity and Uncertainty. Respondents were asked to rate the overall complexity of their most important job-related project, task, or problem. The mean complexity score was 4.3 (of a possible 5.00). Respondents were also asked to rate the amount of technical uncertainty they faced when they started their most important project, task, or problem. The average (mean) technical uncertainty score was 3.7 (of a possible 5.00).

Correlation coefficients (Pearson's $r$ ) were calculated to compare (1) the overall "level of project, task, or problem complexity" and "technical uncertainty" and (2) the level of "project, task, or problem complexity by category" and "technical uncertainty." The correlation coefficients appear in table 3. Positive and significant correlations were found for both comparisons. These findings support the hypothesis that there is a (positive) relationship between technical uncertainty and complexity.

Project, Task, or Problem and Information Use. Respondents were given a list of the following information sources used to complete their most important job-related project, task, or problem: (1) used personal stores of technical information, (2) spoke with coworkers inside the organization, (3) spoke with colleagues outside of the organization, (4) spoke with a librarian/technical information specialist, (5) used literature resources in the organization's library (6) searched (or had someone search for me) an electronic (bibliographic) data base. They were 
Table 1. Survey Demographics

$$
[n=324]
$$

\begin{tabular}{|c|c|c|}
\hline Demographics & Percentage & Number \\
\hline $\begin{array}{l}\text { Do You Currently Work In: } \\
\text { Academia }\end{array}$ & 100.0 & 324 \\
\hline $\begin{array}{l}\text { Is Any Of Your Work Funded By The Government: } \\
\text { Yes } \\
\text { No }\end{array}$ & $\begin{array}{l}70.7 \\
29.3 \\
\end{array}$ & $\begin{array}{r}229 \\
95\end{array}$ \\
\hline $\begin{array}{l}\text { Your Highest Level Of Education: } \\
\text { No Degree } \\
\text { Bachelor's Degree } \\
\text { Master's Degree } \\
\text { Doctorate } \\
\text { Other Type Of Degree }\end{array}$ & $\begin{array}{r}1 \ldots \\
0.9 \\
6.2 \\
92.0 \\
0.9\end{array}$ & $\begin{array}{r}3 \\
20 \\
298 \\
3\end{array}$ \\
\hline $\begin{array}{l}\text { Your Years In Aerospace: } \\
0 \text { years } \\
1 \text { Through } 5 \text { Years } \\
6 \text { Through } 10 \text { Years } \\
11 \text { Through } 20 \text { Years } \\
21 \text { Through } 40 \text { Years } \\
41 \text { Or More Years } \\
\text { Mean }=22.3 \text { Years Median }=22.0 \text { Years }\end{array}$ & $\begin{array}{r}0.3 \\
7.3 \\
14.2 \\
26.9 \\
45.9 \\
5.4\end{array}$ & $\begin{array}{r}1 \\
23 \\
45 \\
85 \\
145 \\
17\end{array}$ \\
\hline $\begin{array}{l}\text { Your Education: } \\
\text { Engineer } \\
\text { Scientist } \\
\text { Other }\end{array}$ & $\begin{array}{r}83.9 \\
13.3 \\
2.8\end{array}$ & $\begin{array}{r}271 \\
43 \\
9\end{array}$ \\
\hline $\begin{array}{l}\text { Your Primary Duties: } \\
\text { Engineer } \\
\text { Scientist } \\
\text { Other }\end{array}$ & $\begin{array}{l}63.5 \\
20.7 \\
15.8\end{array}$ & $\begin{array}{r}205 \\
67 \\
51\end{array}$ \\
\hline $\begin{array}{l}\text { Is Your Work Best Classified As: } \\
\text { Quality Control/Assurance } \\
\text { Research } \\
\text { Management } \\
\text { Design/Development } \\
\text { Manufacturing/Production } \\
\text { Computer Applications } \\
\text { Other }\end{array}$ & $\begin{array}{c}74.8 \\
6.5 \\
3.7 \\
-. \\
2.8 \\
12.1\end{array}$ & $\begin{array}{r}241 \\
21 \\
12 \\
- \\
9 \\
39\end{array}$ \\
\hline $\begin{array}{c}\text { Your Gender: } \\
\text { Female } \\
\text { Male }\end{array}$ & $\begin{array}{r}5.0 \\
95.0\end{array}$ & $\begin{array}{r}16 \\
307\end{array}$ \\
\hline
\end{tabular}


Table 2. Project, Task, or Problem Categorization

\begin{tabular}{|l|c|c|}
\hline Factors & Percentage & Number \\
\hline Categories Of Project, Task, Or Problem: & & \\
Quality Assurance/Control & 74.8 & 241 \\
Research & 3.7 & 12 \\
Design/Development & -- & -- \\
Manufacturing/Production & 2.8 & 9 \\
Computer Applications & 6.5 & 21 \\
Management & 12.1 & 39 \\
Other & & \\
\hline Worked On Project, Task Or Problem: & 24.4 & 78 \\
Alone & 75.6 & 242 \\
With Others & & \\
Mean Number Of Groups =2.6 & & \\
Mean Number of People/Group $=4.4$ & & \\
Nature Of Duties Performed: & 65.0 & 210 \\
Engineering & 18.6 & 60 \\
Science & 8.4 & 27 \\
Management & 8.0 & 26 \\
Other & & \\
\hline
\end{tabular}

Table 3. Correlation of Project Complexity and Technical Uncertainty by Type of Project, Task, or Problem

\begin{tabular}{|l|c|c|}
\hline Complexity - Uncertainty Correlation & $\mathrm{n}$ & $r$ \\
\hline Overall $^{2}$ & 321 & $.000^{* *}$ \\
Quality Assurance/Control $^{*}$ & - &.- \\
Research & 240 & $.001^{* *}$ \\
Design/Development & 12 & .416 \\
Manufacturing/Production &.- &.- \\
Management & 21 & .562 \\
Computer Applications & 9 & .284 \\
Other & 39 & $.000^{* *}$ \\
\hline
\end{tabular}

a Overall mean complexity (uncertainty) score $=4.3$ (3.7) out of a possible 5.00 .

${ }^{* *} r$ values are statistically significant at $p \leq 0.01$.

asked to identify the steps they followed to obtain needed information by sequencing these items

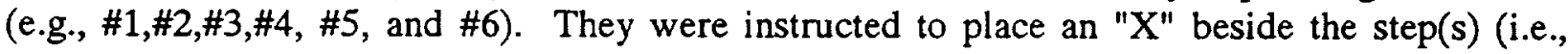
information source) they did not use. The results appear in table 4. 
Table 4. Information Sources Used to Solve Project, Task, or Problem

\begin{tabular}{|c|c|c|c|c|c|c|c|}
\hline Information Source & $\begin{array}{l}\text { Used } \\
\text { First } \\
\%\end{array}$ & $\begin{array}{l}\text { Used } \\
\text { Second } \\
\%\end{array}$ & $\begin{array}{l}\text { Used } \\
\text { Third } \\
\%\end{array}$ & $\begin{array}{l}\text { Used } \\
\text { Fourth } \\
\%\end{array}$ & $\begin{array}{l}\text { Used } \\
\text { Fifth } \\
\%\end{array}$ & $\begin{array}{l}\text { Used } \\
\text { Sixth } \\
\%\end{array}$ & $\begin{array}{l}\text { Not } \\
\text { Used }\end{array}$ \\
\hline $\begin{array}{l}\text { Personal Store Of Technical } \\
\text { Information } \\
\text { Spoke With Coworker(s) }\end{array}$ & 69.7 & 10.9 & 10.9 & 3.6 & 3.3 & 1.0 & 0.7 \\
\hline $\begin{array}{l}\text { Inside The Organization } \\
\text { Spoke With Colleagues } \\
\text { Outside Of The }\end{array}$ & 8.0 & 32.5 & 18.9 & 14.3 & 8.0 & 2.4 & 15.7 \\
\hline $\begin{array}{l}\text { Outside Of The } \\
\text { Organization } \\
\text { Used Literature Resources } \\
\text { In My Organization's }\end{array}$ & 7.8 & 17.3 & 26.9 & 17.7 & 12.6 & 5.8 & 11.9 \\
\hline $\begin{array}{l}\text { Library } \\
\text { Spoke With A Librarian/ } \\
\text { Technical Information } \\
\text { Specialist }\end{array}$ & 9.3 & 20.7 & 19.3 & 16.9 & 13.8 & 4.8 & 15.2 \\
\hline $\begin{array}{l}\text { Specialist } \\
\text { Searched (Or Had Someone } \\
\text { Search For Me) An Electronic } \\
\text { (Bibliographic) Data Base }\end{array}$ & 6.9 & 18.6 & 19.2 & 18.9 & 11.3 & 13.7 & 22.7 \\
\hline
\end{tabular}

Use of Federally Funded Aerospace R\&D. About $85 \%$ (274) of the participants used the results of federally funded aerospace R\&D in their work. Respondents who used federally funded aerospace $R \& D$ in their work were given a list of 12 sources. They were asked to indicate how they learned about the results of federally funded aerospace R\&D from each of the 12 sources (Table 5). Of the six most frequently used sources, half involve interpersonal communication and half are formal (written) communication. One of the five "federal initiatives" was the source used least to learn about the results of federally funded aerospace R\&D. NASA and DoD technical reports and NASA and DoD contacts were the exception.

The respondents who reported using the results of federally funded aerospace $R \& D$ were asked if they used these results in completing the most important job-related project, task, or problem they had worked on in the past 6 months. The 84\% (231) of respondents who answered "yes" were asked about the importance of these results in completing the project, task, or problem. A 5-point scale $(1.0=$ not at all important, $5.0=$ very important $)$ was used to measure importance. The mean importance rating was 4.2 . Almost $80 \%$ of those who used federally funded R\&D (185 respondents) responded with an importance rating of "4" or "5". About $68 \%$ (156) of those who used the results of federally funded aerospace R\&D in completing their most important job-related project, task, or problem indicated that the results were published in either a NASA or DoD technical report. 
Table 5. Sources Used to Learn About

the Results of Federally Funded Aerospace R\&D

\begin{tabular}{|l|c|c|}
\hline Source & Percentage & Number \\
\hline 1. Professional And Society Journals & 89.6 & 206 \\
2. Coworkers Inside My Organization & 61.4 & 135 \\
3. Trade Journals & 27.6 & 60 \\
4. NASA And DoD Technical Reports & 76.0 & 168 \\
5. Colleagues Outside My Organization & 78.6 & 176 \\
6. NASA And DoD Contacts & 75.2 & 170 \\
7. Professional And Society Meetings & 86.7 & 196 \\
8. Searches of Computerized Data Bases & 68.3 & 153 \\
9. NASA And DoD Sponsored & & \\
Conferences And Workshops & 62.1 & 136 \\
10. Visits To NASA And DoD Facilities & 57.7 & 128 \\
11. Publications Such As STAR & 24.0 & 52 \\
12. Librarians Inside My Organization & 25.9 & 55 \\
\hline
\end{tabular}

The respondents who used the results of federally funded aerospace $R \& D$ in completing their most important job-related project, task, or problem were asked which problems, if any, they encountered in using these results (see table 6). Respondents were given a list of six problems from which to choose. About $61 \%$ indicated that the "time and effort it took to locate the results" was a problem. About $63 \%$ reported that the "time and effort it took to physically obtain the results" was a problem. About $26 \%$ indicated that "accuracy, precision, and reliability of the results" was a problem, and about $29 \%$ reported that "distribution limitations or security restrictions" constituted a problem. About $20 \% / 22 \%$ indicated that "organization or format"/"legibility or readability" of the results constituted a problem.

\section{Technical Communications Practices}

Data which describe factors concerning the production and use of technical information are summarized in table 7. Participants were asked to indicate the importance of communicating technical information effectively (e.g., producing written materials or oral discussions). A 5-point scale was used to measure importance $(1.0=$ not at all important; $5.0=$ very important $)$.

Importance and Time Spent. The mean importance rating was 4.8 ; approximately $90 \%$ of respondents indicated that it was important to communicate technical information effectively. Respondents were also asked to report the total number of hours per week they had spent communicating technical information, both in written form and orally, during the past 6 months. Respondents reported spending slightly more time on producing written materials (an average of 
Table 6. Problems Related to Use of Federally-Funded Aerospace R\&D

\begin{tabular}{|l|c|c|}
\hline Problem & Percentage & Number \\
\hline Time And Effort To Locate Results & 61.1 & 146 \\
Time And Effort To Obtain Results & 63.2 & 151 \\
Accuracy, Precision And Reliability & 26.4 & 63 \\
Of Results & & \\
Distribution Limitations Or Security & 28.9 & 69 \\
Restrictions Of Results & 20.1 & 48 \\
Organization Or Format Of Results & 21.8 & 52 \\
Legibility Or Readability Of Results & \\
\hline
\end{tabular}

12.1 hours/week) than oral discussions (an average of 11.6 hours/week). Approximately $53 \%$ of the respondents indicated that the amount of time they spent communicating technical information to others had increased over the past 5 years. About $5 \%$ indicated a decrease in the amount of time spent communicating technical information to others over the same period.

Respondents were also asked to report the total number of hours per week spent working with technical information, both written and oral, received from others in the past 6 months (see table 7). Respondents reported spending more time working with written technical information received from others (an average of 9.4 hours/week) than with technical information received orally from others (an average of 5.0 hours/week). Approximately $57 \%$ of the respondents indicated that, as they have advanced professionally, the amount of time spent working with technical information received from others had increased. About 10\% indicated a decrease in the amount of time they spent working with technical information received from others.

Collaborative Writing. An attempt was made to determine the amount of writing in U.S. aerospace that is collaborative. Survey participants were asked to indicate the percentage of their written technical communications in the past 6 months that involved writing alone, with one other person, with a group of two to five people, and with a group of more than five people. About $16 \%$ of the survey respondents indicated that about $100 \%$ of the written technical communications they prepared involved writing alone. [The mean percent was $(\overline{\mathrm{X}}=59.8)$ and the median percent was 70.0.] About $72 \%$ indicated that their written technical communications involved writing with one other person. [The mean percent was $(\bar{X}=23.0)$ and the median percent was 20.0.] About 54\% indicated that their written technical communications involved writing with a group of two to five people. [The mean percent was $(\overline{\mathrm{X}}=14.5)$ and the median percent was 5.0.] About 10\% indicated that their written technical communications involved writing with a group of more than five people. [The mean percent was $(\bar{X}=1.8)$ and the median percent was 0.0.] 
Table 7. Technical Communications: Importance, Time Spent, and Change Over Time

\begin{tabular}{|c|c|c|}
\hline Communication And Receipl Of Information & Percentage & Number \\
\hline $\begin{array}{l}\text { Importance Of Communicating Technical Information: } \\
\text { Unimportant } \\
\text { Neither important Nor Unimportant } \\
\text { Important } \\
\text { Mean }=4.8 \text { Median }=5.0\end{array}$ & $\begin{array}{r}1.5 \\
8.0 \\
90.5\end{array}$ & $\begin{array}{r}5 \\
26 \\
293\end{array}$ \\
\hline $\begin{array}{l}\text { Time Spent Producing Written Technical Information: } \\
0 \text { Hours Per Week } \\
1 \text { Through } 5 \text { Hours Per Week } \\
6 \text { Through } 10 \text { Hours Per Week } \\
11 \text { Through } 15 \text { Hours Per Week } \\
16 \text { Through } 20 \text { Hours Per Week } \\
21 \text { Or More Hours Per Week } \\
\text { Mean }=12.1 \text { Median }=10.0\end{array}$ & $\begin{array}{r}0.9 \\
22.0 \\
40.3 \\
11.6 \\
16.4 \\
8.8\end{array}$ & $\begin{array}{r}3 \\
70 \\
128 \\
37 \\
52 \\
28\end{array}$ \\
\hline $\begin{array}{l}\text { Time Spent Communicating Technical Information Orally: } \\
0 \text { Hours Per Week } \\
1 \text { Through } 5 \text { Hours Per Week } \\
6 \text { Through } 10 \text { Hours Per Week } \\
11 \text { Through } 15 \text { Hours Per Week } \\
16 \text { Through } 20 \text { Hours Per Week } \\
21 \text { Or More Hours Per Week } \\
\text { Mean }=11.6 \text { Median }=10.0\end{array}$ & $\begin{array}{r}1.3 \\
22.8 \\
36.9 \\
16.3 \\
16.7 \\
6.1\end{array}$ & $\begin{array}{r}4 \\
71 \\
115 \\
51 \\
52 \\
19\end{array}$ \\
\hline $\begin{array}{l}\text { Change Over Past } 5 \text { Years In The Amount Of Time Spent } \\
\text { Communicating Technical Information To Others: } \\
\text { Increased } \\
\text { Stayed The Same } \\
\text { Decreased }\end{array}$ & $\begin{array}{r}52.6 \\
42.1 \\
5.3\end{array}$ & $\begin{array}{r}169 \\
135 \\
17\end{array}$ \\
\hline $\begin{array}{l}\text { Time Spent Working With Written Technical Information } \\
\text { Received From Others: } \\
0 \text { Hours Per Week } \\
1 \text { Through } 5 \text { Hours Per Week } \\
6 \text { Through } 10 \text { Hours Per Week } \\
11 \text { Through } 15 \text { Hours Per Week } \\
16 \text { Through } 20 \text { Hours Per Week } \\
21 \text { Or More Hours Per Week } \\
\text { Mean }=9.4 \text { Median }=10.0\end{array}$ & $\begin{array}{r}0.3 \\
36.9 \\
42.6 \\
7.3 \\
9.5 \\
3.5\end{array}$ & $\begin{array}{r}1 \\
117 \\
135 \\
23 \\
30 \\
11\end{array}$ \\
\hline $\begin{array}{l}\text { Time Spent Working with Technical Information Received Orally From Others: } \\
0 \text { Hours Per Week } \\
1 \text { Through } 5 \text { Hours Per Week } \\
6 \text { Through } 10 \text { Hours Per Week } \\
11 \text { Through } 15 \text { Hours Per Week } \\
16 \text { Through } 20 \text { Hours Per Week } \\
21 \text { Or More Hours Per Week } \\
\text { Mean }=5.0 \text { Median }=4.0\end{array}$ & $\begin{array}{r}3.4 \\
73.4 \\
18.4 \\
1.7 \\
3.1 \\
0.0\end{array}$ & $\begin{array}{r}10 \\
215 \\
54 \\
5 \\
9 \\
0\end{array}$ \\
\hline $\begin{array}{l}\text { Professional Advancement And Changes In Amount Of Time Spent Working } \\
\text { With Technical Information Received From Others: } \\
\text { Increased } \\
\text { Stayed The Same } \\
\text { Decreased }\end{array}$ & $\begin{array}{l}57.2 \\
32.5 \\
10.3\end{array}$ & $\begin{array}{r}183 \\
104 \\
33\end{array}$ \\
\hline
\end{tabular}


Survey participants who write collaboratively were asked if they find writing as part of a group more or less productive (i.e., producing more written products or producing better written products) than writing alone. The responses appear in table 8 . Overall, slightly more of the respondents indicated that writing with a group is more productive than writing alone. About $35 \%$ indicated that a group is more productive and about $32 \%$ indicated that a group is less productive. About $34 \%$ indicated that a group is about as productive as writing alone.

Table 8. Influence of Group Participation on Writing Productivity

\begin{tabular}{|l|c|c|}
\hline How Productive & Percentage & Number \\
\hline A Group Is More Productive Than Writing Alone & 35.0 & 92 \\
A Group Is About As Productive As Writing Alone & 33.5 & 88 \\
A Group Is Less Productive Than Writing Alone & 31.6 & 83 \\
\hline
\end{tabular}

Survey participants were asked if, during that 6 month period, they had worked with the same group of people when producing written technical communications. About 46\% (124 respondents) indicated "yes" they had worked with the same group, and about 54\% indicated that they had worked with various groups. Of those who indicated that they had worked in the same group, these respondents were asked how many people were in the group. About 87\% (107 respondents) indicated a group size of 2-5 people and about $7 \%$ ( 8 respondents) indicated a group size of 6-10 people. The mean number of people in the group was $\overline{\mathrm{X}}=3.4$ and the median was 3.0.

Those 143 respondents who indicated "no," meaning that they did not work with the same group during the past 6 months, were asked with about how many groups they had worked. About $21 \%$ ( 29 respondents) reported working with 2 groups, about $42 \%$ ( 59 respondents) reported working with 3 groups, about $16 \%$ ( 22 respondents) reported working with 4 groups, about $11 \%$ ( 16 respondents) reported working with 5 groups, and about $11 \%$ (15 respondents) reported working with 6-10 groups. The average (mean) number of groups was $\overline{\mathrm{X}}=3.7$ and the median number of groups was 3.0. The number of people in each group varied. About $90 \%$ of the respondents reported working with a group of $2-5$ people and about $4 \%$ reported working with a group of 6-10 people. The average (mean) number of people per group was $\overline{\mathrm{X}}=3.5$ and the median number of people per group was 3.0.

Technical Information Products Produced. Survey participants were given a list of technical information products. They were asked to indicate the number of these products they had written or otherwise prepared in the past 6 months and if those products had been written or prepared as part of a group. The 10 most frequently produced (alone) technical information products appear in table 9.

Survey participants were also asked to indicate the number of these products they had written or otherwise prepared in the past 6 months as part of a group. The 10 most frequently prepared (as part of a group) technical information products appear in table 10. Data shown in table 10 
include the number of products produced (mean and median) and the average (mean and median) numbers of people per group.

Table 9. Technical Information Products Written or Produced Alone in the Past 6 Months

\begin{tabular}{|l|c|c|}
\hline Products & Mean $(\overline{\mathrm{X}})$ & Median \\
\hline Memoranda & 18.9 & 2.0 \\
Letters & 33.7 & 10.0 \\
Drawings/Specifications & 1.4 & 0.0 \\
Abstracts & 1.3 & 1.0 \\
Audio/Visual Materials & 4.8 & 0.0 \\
In-house Technical Reports & 0.5 & 0.0 \\
Computer Program Documentation & 0.4 & 0.0 \\
Conference/Meeting Papers & 0.8 & 0.0 \\
Technical Talks/Presentations & 5.3 & 2.0 \\
Technical Proposals & 1.5 & 0.0 \\
\hline
\end{tabular}

A comparison of the data contained in tables 9 and 10 reveals more similarities than differences. The production numbers vary but the products included on both lists (products produced alone or as part of a group) are essentially identical. The average numbers of people per group for the various products produced are fairly similar in size.

Survey participants were given a list of technical information products. They were asked to indicate approximately how many times in the past 6 months they had used each of them. The 10 most frequently used technical information products appear in table 11. A comparison of the data contained in tables 9 (production) and 11 (use) reveals two differences. First, on average, more products are used than are produced. Second, there are slight differences in the types or kinds of products produced and used.

\section{Technical Information Products -- Use, Importance, and Frequency of Use}

Survey participants were asked several questions designed to obtain a greater understanding of the factors affecting the use of technical reports. In this study, technical reports were placed within the context of two technical information products: conference/meeting papers and journal articles. DoD, in-house, and NASA technical reports were included in this study.

Use. Survey participants were asked if they used the aforementioned technical information products in performing their present professional duties. Table 12 includes data regarding use. 
Table 10. Technical Information Products Written or Produced as Part of a Group in the Past 6 Months

\begin{tabular}{|l|c|c|c|c|}
\hline \multirow{2}{*}{ Information Products } & \multicolumn{2}{|c|}{} & \multicolumn{2}{c|}{$\begin{array}{c}\text { Average Number of } \\
\text { People Per Group }\end{array}$} \\
\cline { 2 - 5 } & Mean $(\overline{\mathrm{X}})$ & Median & Mean $(\overline{\mathrm{X}})$ & Median \\
\hline Drawings/Specifications & 0.8 & 0.0 & 2.7 & 2.0 \\
Letters & 1.1 & 0.0 & 4.2 & 2.0 \\
Memoranda & 0.4 & 0.0 & 2.1 & 2.0 \\
Audio/Visual Materials & 1.1 & 0.0 & 3.6 & 2.0 \\
Conference/Meeting Papers & 1.6 & 1.0 & 2.9 & 2.0 \\
Trade/Promotional Literature & 0.4 & 0.0 & 4.1 & 2.0 \\
Technical Talks/Presentations & 1.0 & 0.0 & 4.1 & 2.0 \\
Abstracts & 1.4 & 0.0 & 2.5 & 2.0 \\
Journal Articles & 1.4 & 1.0 & 2.5 & 2.0 \\
Technical Proposals & 0.9 & 0.0 & 3.0 & 3.0 \\
\hline
\end{tabular}

Table 11. Technical Information Product Used in the Past 6 Months

\begin{tabular}{|l|c|c|}
\hline Information Products & Mean $(\overline{\mathrm{X}})$ & Median \\
\hline Journal Articles & 20.6 & 10.0 \\
Memoranda & 20.8 & 0.0 \\
Letters & 29.0 & 4.0 \\
Trade/Promotional Literature & 4.8 & 0.0 \\
Drawings/Specifications & 3.6 & 0.0 \\
Abstracts & 12.1 & 3.0 \\
Audio/Visual Materials & 6.1 & 0.0 \\
Computer Program Documentation & 3.2 & 0.0 \\
Conference/Meeting Papers & 12.6 & 6.0 \\
Technical Talks/Presentations & 7.7 & 1.0 \\
\hline
\end{tabular}

Table 12. Technical Information Products Used

\begin{tabular}{|l|c|c|}
\hline Information Products & Percentage & Number \\
\hline Conference/Meeting Papers & 95.3 & 305 \\
Journal Articles & 97.2 & 312 \\
In-house Technical Reports & 53.7 & 158 \\
DoD Technical Reports & 56.4 & 171 \\
NASA Technical Reports & 81.1 & 253 \\
\hline
\end{tabular}


Importance. Survey participants were asked "how important is it for you to use the aforementioned technical information products in performing your present professional duties?" Table 13 includes data regarding the importance of technical information products. A 5-point scale $(1.0=$ not at all important; $5.0=$ very important $)$ was used to measure importance.

Table 13. Importance of Technical Information Products

\begin{tabular}{|l|c|c|}
\hline Information Products & Mean $(\overline{\mathrm{X}})$ Importance & Number \\
\hline Conference/Meeting Papers & 4.2 & 322 \\
Journal Articles & 4.5 & 322 \\
In-house Technical Reports & 2.6 & 303 \\
DoD Technical Reports & 2.8 & 307 \\
NASA Technical Reports & 3.4 & 320 \\
\hline
\end{tabular}

Approximately $79 \%$ (254 respondents) indicated that the use of conference/meeting papers was "very or somewhat"important to their work. Approximately $90 \%$ (290 respondents) indicated that the use of joumal articles was "very or somewhat" important to their work. Approximately $26 \%$ (78 respondents) indicated that in-house technical reports were "very or somewhat" important to their work. Approximately 28\% (87 respondents) and 50\% (160 respondents), respectively, indicated that DoD and NASA technical reports were "very or somewhat" important to their work.

Frequency of Use. Survey participants were asked to indicate the number of times each of the five technical information products had been used in a 6 month period in the performance of their professional duties (table 14). Data are presented both as means and medians. Journal

Table 14. Average Number of Times (Median) Technical Information Products Used in a 6 Month Period

\begin{tabular}{|l|c|c|}
\hline Information Products & Mean $(\overline{\mathrm{X}})$ Use & Median \\
\hline Conference/Meeting Papers & 12.6 & 6.0 \\
Journal Articles & 20.6 & 10.0 \\
In-house Technical Reports & 1.1 & 0.0 \\
DoD Technical Reports & 1.2 & 0.0 \\
NASA Technical Reports & 2.5 & 0.0 \\
\hline
\end{tabular}

articles were used $(\bar{X}=20.6)$ to a much greater extent than were the other technical information products. Conference/meeting papers $(\overline{\mathrm{X}}=12.6)$ were used to a lesser extent followed by NASA $(\bar{X}=2.5)$, DoD technical reports $(\bar{X}=1.2)$, and in-house technical reports $(\bar{X}=1.1)$. 


\section{Technical Information Products -. Factors Affecting Use}

Even if they did not use them, survey participants were asked if they were deciding whether or not to use any of the five technical information products in performing their present professional duties, how important each of the eight characteristics (factors) would be in making that decision. For example, respondents were asked to indicate how important the factor, "they are easy to physically obtain," would be in making a decision to use conference/meeting papers. A 5 -point scale $(1.0=$ not at all important; $5.0=$ very important $)$ was used to measure importance. The higher the number, the greater the influence of the factor on the use of conference/meeting papers. An overall mean $(\overline{\mathrm{X}})$ rating was calculated. A mean $(\overline{\mathrm{X}})$ rating for users and non-users of each product is presented.

Conference/Meeting Papers. The importance factor ratings for conference/meeting papers appear in table 15. The factors exerting the greatest influence on use were (1) relevant to my work $(\bar{X}=4.8),(2)$ good technical quality $(\bar{X}=4.6)$, (3) comprehensive data and information $(\bar{X}$ $=4.4),(4)$ easy to physically obtain $(\vec{X}=4.3)$, and (5) easy to use or read $(\bar{X}=4.1)$.

Table 15. Factors Affecting the Use of Conference/Meeting Papers

\begin{tabular}{|l|c|c|c|}
\hline \multirow{2}{*}{ Factors } & $\begin{array}{c}\text { User } \\
\text { Rating }(\overline{\mathrm{X}})\end{array}$ & $\begin{array}{c}\text { Non-User } \\
\text { Rating }(\overline{\mathrm{X}})\end{array}$ & $\begin{array}{c}\text { Overall } \\
\text { Rating }(\overline{\mathrm{X}})\end{array}$ \\
\cline { 2 - 4 } & $\mathrm{n}=305$ & $\mathrm{n}=15$ & $\mathrm{n}=324$ \\
\hline Are Easy To Physically Obtain & 4.3 & 4.3 & 4.3 \\
Are Easy To Use Or Read & 4.1 & 4.0 & 4.1 \\
Are Inexpensive & 3.8 & 3.8 & 3.8 \\
Have Good Technical Quality & 4.6 & 4.1 & 4.6 \\
Have Comprehensive Data And Information & 4.4 & 3.9 & 4.4 \\
Are Relevant To My Work & 4.8 & 4.7 & 4.8 \\
Can Be Obtained At A Nearby Location Or Source & 3.8 & 3.8 & 3.8 \\
Had Good Prior Experiences Using Them & 3.5 & 3.5 & 3.5 \\
\hline
\end{tabular}

Journal Articles. The importance factor ratings for journal articles appear in table 16. The factors exerting the greatest influence on use were (1) relevant to my work $(\bar{X}=4.8)$, (2) good technical quality $(\bar{X}=4.7)$, (3) comprehensive data and information $(\bar{X}=4.4)$, (4) easy to physically obtain $(\overline{\mathrm{X}}=4.2)$, and (5) easy to use or read $(\overline{\mathrm{X}}=4.1)$. 
Table 16. Factors Affecting the Use of Journal Articles

\begin{tabular}{|l|c|c|c|}
\hline & $\begin{array}{c}\text { User } \\
\text { Rating }(\overline{\mathrm{X}})\end{array}$ & $\begin{array}{c}\text { Non-User } \\
\text { Rating }(\overline{\mathrm{X}})\end{array}$ & $\begin{array}{c}\text { Overall } \\
\text { Rating }(\overline{\mathrm{X}})\end{array}$ \\
\cline { 2 - 4 } Factors & $\mathrm{n}=312$ & $\mathrm{n}=9$ & $\mathrm{n}=324$ \\
\hline Are Easy To Physically Obtain & 4.2 & 4.9 & 4.2 \\
Are Easy To Use Or Read & 4.1 & 4.8 & 4.1 \\
Are Inexpensive & 3.6 & 4.1 & 3.6 \\
Have Good Technical Quality & 4.7 & 4.6 & 4.7 \\
Have Comprehensive Data And Information & 4.4 & 4.5 & 4.4 \\
Are Relevant To My Work & 4.8 & 4.8 & 4.8 \\
Can Be Obtained At A Nearby Location Or Source & 3.7 & 4.4 & 3.7 \\
Had Good Prior Experiences Using Them & 3.6 & 3.6 & 3.6 \\
\hline
\end{tabular}

In-house Technical Reports. The importance factor ratings for in-house technical reports appear in table 17. The factors exerting the greatest influence on use were (1) relevant to my work $(\bar{X}=4.7),(2)$ good technical quality $(\bar{X}=4.5),(3)$ comprehensive data and information $(\bar{X}$ $=4.4)$, (4) easy to physically obtain $(\bar{X}=4.1)$, and (5) easy to use or read $(\bar{X}=4.0)$.

DoD Technical Reports. The importance factor ratings for DoD technical reports appear in table 18. The factors exerting the greatest influence on use were (1) relevant to my work $(\overline{\mathrm{X}}=$ 4.6), (2) good technical quality $(\bar{X}=4.5)$, (3) comprehensive data and information $(\bar{X}=4.3),(4)$ easy to physically obtain $(\bar{X}=4.1)$, and (5) easy to use or read $(\bar{X}=4.0)$.

Table 17. Factors Affecting the Use of In-house Technical Reports

\begin{tabular}{|l|c|c|c|}
\hline \multirow{2}{*}{ Factors } & $\begin{array}{c}\text { User } \\
\text { Rating }(\overline{\mathrm{X}})\end{array}$ & $\begin{array}{c}\text { Non-User } \\
\text { Rating }(\overline{\mathrm{X}})\end{array}$ & $\begin{array}{c}\text { Overall } \\
\text { Rating }(\overline{\mathrm{X}})\end{array}$ \\
\cline { 2 - 4 } & $\mathrm{n}=158$ & $\mathrm{n}=136$ & $\mathrm{n}=324$ \\
\hline Are Easy To Physically Obtain & 4.1 & 3.6 & 3.8 \\
Are Easy To Use Or Read & 4.0 & 3.4 & 3.7 \\
Are Inexpensive & 3.5 & 3.2 & 3.3 \\
Have Good Technical Quality & 4.5 & 3.8 & 4.2 \\
Have Comprehensive Data And Information & 4.4 & 3.7 & 4.1 \\
Are Relevant To My Work & 4.7 & 3.9 & 4.4 \\
Can Be Obtained At A Nearby Location & 3.8 & 3.3 & 3.5 \\
Had Good Prior Experiences Using Them & 3.8 & 2.8 & 3.3 \\
\hline
\end{tabular}


Table 18. Factors Affecting the Use of DoD Technical Reports

\begin{tabular}{|l|c|c|c|}
\hline \multirow{2}{*}{ Factors } & $\begin{array}{c}\text { User } \\
\text { Rating }(\overline{\mathrm{X}})\end{array}$ & $\begin{array}{c}\text { Non-User } \\
\text { Rating }(\overline{\mathrm{X}})\end{array}$ & $\begin{array}{c}\text { Overall } \\
\text { Rating }(\overline{\mathrm{X}})\end{array}$ \\
\cline { 2 - 4 } & $\mathrm{n}=171$ & $\mathrm{n}=132$ & $\mathrm{n}=324$ \\
\hline Are Easy To Physically Obtain & 4.1 & 3.9 & 4.0 \\
Are Easy To Use Or Read & 4.0 & 3.7 & 3.8 \\
Are Inexpensive & 3.8 & 3.4 & 3.6 \\
Have Good Technical Quality & 4.5 & 4.2 & 4.3 \\
Have Comprehensive Data And Information & 4.3 & 4.1 & 4.2 \\
Are Relevant To My Work & 4.6 & 4.4 & 4.5 \\
Can Be Obtained At A Nearby Location Or Source & 3.6 & 3.6 & 3.6 \\
Had Good Prior Experiences Using Them & 3.5 & 3.2 & 3.4 \\
\hline
\end{tabular}

NASA Technical Reports. The importance factor ratings for NASA technical reports appear in table 19. The factors exerting the greatest influence on use were (1) relevant to my work $(\bar{X}$ $=4.7$ ), (2) good technical quality $(\bar{X}=4.6)$, (3) comprehensive data and information $(\bar{X}=4.4)$, (4) easy to physically obtain $(\bar{X}=4.2)$, and (5) easy to use or read $(\bar{X}=4.1)$.

Table 19. Factors Affecting the Use of NASA Technical Reports

\begin{tabular}{|l|c|c|c|}
\hline & $\begin{array}{c}\text { User } \\
\text { Rating }(\overline{\mathrm{X}})\end{array}$ & $\begin{array}{c}\text { Non-User } \\
\text { Rating }(\overline{\mathrm{X}})\end{array}$ & $\begin{array}{c}\text { Overall } \\
\text { Rating }(\overline{\mathrm{X}})\end{array}$ \\
\cline { 2 - 4 } Factors & $\mathrm{n}=253$ & $\mathrm{n}=59$ & $\mathrm{n}=324$ \\
\hline Are Easy To Physically Obtain & 4.2 & 4.1 & 4.2 \\
Are Easy To Use Or Read & 4.1 & 3.9 & 4.0 \\
Are Expensive & 3.7 & 3.5 & 3.7 \\
Have Good Technical Quality & 4.6 & 4.5 & 4.5 \\
Having Comprehensive Data And Information & 4.4 & 4.4 & 4.4 \\
Are Relevant To My Work & 4.7 & 4.6 & 4.7 \\
Can Be Obtained At A Nearby Location Or Source & 3.8 & 3.6 & 3.7 \\
Had Good Prior Experiences Using Them & 3.7 & 3.0 & 3.6 \\
\hline
\end{tabular}




\section{Use of Computer and Information Technology}

Survey participants were asked if they use computer technology to prepare (written) technical communications. Almost all (98\%) (309) of the survey respondents use computer technology to prepare (written) technical information. About 70\% (222) of the respondents "always" use computer technology to prepare (written) technical information. About $98 \%$ (309) indicated that computer technology had increased their ability to communicate technical information. About $82 \%$ (257) of the respondents stated that computer technology had increased their ability to communicate technical information "a lot".

From a prepared list, survey respondents were asked to indicate which computer software they used to prepare written technical communication (table 20). Word processing software was used most frequently by survey respondents, followed by spelling checkers, scientific graphics, and thesauruses. Outliners and prompters and business graphics were "least frequently" used to prepare written technical communication.

Table 20. Use of Computer Software to Prepare Written Technical Communication

\begin{tabular}{|l|c|c|}
\hline Software & Percentage & Number \\
\hline Word Processing & 99.4 & 312 \\
Outliners And Prompters & 16.9 & 37 \\
Grammar And Style Checkers & 48.8 & 121 \\
Spelling Checkers & 92.4 & 281 \\
Thesauruses & 53.9 & 130 \\
Business Graphics & 31.9 & 72 \\
Scientific Graphics & 90.3 & 271 \\
Desktop Publishing & 44.7 & 109 \\
\hline
\end{tabular}

Survey respondents were also given a list of information technologies and asked, "How do you view your use of the following information technologies in communicating technical information?" Their choices included "already use it"; "don't use it, but may in the future"; and "don't use it and doubt if I will". (See table 21.) The aerospace engineering educators in this study use a variety of information technologies. The percentages of "I already use it" responses ranged from a high of $97.5 \%$ (FAX or TELEX) to a low of $17.5 \%$ (video conferencing). 
A list, in descending order, follows of the information technologies most frequently used.

$\begin{array}{ll}\text { FAX or TELEX } & 97.5 \% \\ \text { Electronic Mail } & 96.0 \\ \text { Electronic Networks } & 77.4 \\ \text { Videotape } & 65.7 \\ \text { Electronic Databases } & 62.2\end{array}$

A list, in descending order, follows of the information technologies "that are not currently being used but may be used in the future."

Video Conferencing

Laser Disk/Video Disk/CD-ROM

Electronic Bulletin Boards

Micrographics and Microforms

Desktop/Electronic Publishing
$66.7 \%$

42.6

40.5

36.7

34.0

Table 21. Use, Nonuse, and Potential Use of Information Technologies

\begin{tabular}{|c|c|c|c|c|c|c|}
\hline \multirow[b]{2}{*}{ Information Technologies } & \multicolumn{2}{|c|}{ Already Use It } & \multicolumn{2}{|c|}{$\begin{array}{c}\text { Don't Use It, } \\
\text { But May In } \\
\text { Future }\end{array}$} & \multicolumn{2}{|c|}{$\begin{array}{l}\text { Don't Use It, } \\
\text { And Doubt If } \\
\text { Will }\end{array}$} \\
\hline & $\%$ & (n) & $\%$ & (n) & $\%$ & (n) \\
\hline Audio Tapes And Cassettes & 23.0 & 69 & 25.0 & 75 & 52.0 & 156 \\
\hline Motion Picture Films & 23.9 & 71 & 25.9 & 77 & 50.2 & 149 \\
\hline Videotape & 65.7 & 205 & 25.3 & 79 & 9.0 & 28 \\
\hline Desktop/Electronic Publishing & 54.8 & 166 & 34.0 & 103 & 11.2 & 34 \\
\hline Computer Cassettes/Cartridge Tapes & 40.3 & 119 & 28.5 & 84 & 31.2 & 92 \\
\hline Electronic Mail & 96.0 & 310 & 4.0 & 13 & 0.0 & 0 \\
\hline Electronic Bulletin Boards & 47.2 & 141 & 40.5 & 121 & 12.4 & 37 \\
\hline FAX or TELEX & 97.5 & 313 & 2.5 & 8 & 0.0 & 0 \\
\hline Electronic Data Bases & 62.2 & 186 & 33.1 & 99 & 4.7 & 14 \\
\hline Video Conferencing & 17.5 & 52 & 66.7 & 198 & 15.8 & 47 \\
\hline Micrographics And Microforms & 25.3 & 71 & 36.7 & 103 & 38.1 & 107 \\
\hline Laser Disk/Video Disk/CD-ROM & 50.2 & 153 & 42.6 & 130 & 7.2 & 22 \\
\hline Electronic Networks & 77.4 & 240 & 18.4 & 57 & 4.2 & 13 \\
\hline
\end{tabular}




\section{Use and Importance of Electronic (Computer) Networks}

Survey participants were asked if they use electronic (computer) networks in their workplace in performing their present duties. About $77 \%$ of the respondents use electronic networks in performing their present duties and about $23 \%$ either do not use (20\%), or do not have access to (3\%) electronic networks. Survey respondents used electronic networks an average of 10.9 hours per week. (See table 22.)

Table 22. Use of Electronic (Computer) Networks in One Week

\begin{tabular}{|l|c|c|}
\hline Use & Percentage & Number \\
\hline 0 Hours & 0.4 & 1 \\
- 10 Hours & 71.5 & 203 \\
11 - 25 Hours & 17.6 & 50 \\
26 50 Hours & 9.5 & 27 \\
51 Or More Hours & 1.1 & 3 \\
\hline Mean & \multicolumn{2}{|}{} \\
Median & 10.9 & \\
\hline
\end{tabular}

Respondents who use them were also asked to rate the importance of electronic (computer) networks in performing their present duties (table 23). Importance was measured on a 5-point scale with $1=$ not at all important and $5=$ very important. About $83 \%$ of the respondents rated electronic networks important. About $12 \%$ rated them neither important nor unimportant, and about $6 \%$ rated electronic networks as unimportant.

Table 23. Importance of Electronic (Computer) Networks

\begin{tabular}{|l|c|c|}
\hline Importance & Percentage & Number \\
\hline Important & 82.8 & 237 \\
Neither Important Nor Unimportant & 11.5 & 33 \\
Unimportant & 5.5 & 16 \\
\hline
\end{tabular}

Respondents were asked how they accessed electronic (computer) networks (table 24): mainframe terminal, personal computers, and workstations. Access via personal computer (77.8\%) was most frequently reported. Access via mainframe terminal/workstation was reported by $16.0 \% / 42.7 \%$ of the survey respondents. 
Table 24. How Electronic (Computer) Networks are Accessed

\begin{tabular}{|l|c|c|}
\hline Access & $\%$ & $(\mathrm{n})$ \\
\hline Mainframe Terminal & 16.0 & 46 \\
Personal Computer & 77.8 & 224 \\
Workstation & 42.7 & 123 \\
\hline
\end{tabular}

Respondents using them were asked to indicate the purpose(s) for which they used electronic (computer) networks (table 25). Survey respondents indicated that electronic mail (99.3\%), WWW (89.8\%), connect to geographically distant sites (88.4\%), accessing/searching the library's catalog $(83.5 \%)$, and information search and retrieval using FTP $(79.2 \%)$ represented their greatest use of electronic networks. Noticeable is the lack of electronic network use for acquiring (ordering) documents from the library and preparing scientific papers with colleagues at geographically distant sites.

Table 25. Use of Electronic (Computer) Networks for Specific Purposes

\begin{tabular}{|l|c|c|}
\hline Purpose & Percentage & Number \\
\hline Connect To Geographically Distant Sites & 88.4 & 244 \\
Electronic Mail & 99.3 & 284 \\
Electronic Bulletin Boards Or Conferences & 54.9 & 146 \\
Access/Search The Library's Catalog & 83.5 & 233 \\
Order Documents From The Library & 33.9 & 86 \\
Search Electronic (Bibliographic) Data Bases & 70.5 & 189 \\
Prepare Scientific And Papers With & & \\
Colleagues At Geographically Distant Sites & 54.1 & 140 \\
For Information Search/Data Retrieval With The Following & & \\
FTP & 79.2 & 209 \\
Gopher & 51.5 & 124 \\
WAIS & 12.1 & 26 \\
World Wide Web (WWW) & 89.8 & 247 \\
\hline
\end{tabular}

Survey participants who used electronic (computer) networks were asked to identify the groups with whom they exchanged messages or files (table 26). An average of $89 \%$ of the survey respondents used electronic networks to exchange files with members of their own work group and others in their organization but not in their work group. 
Table 26. Use of Electronic (Computer) Networks to Exchange Messages or Files

\begin{tabular}{|l|c|c|}
\hline Exchange With -- & Percentage & Number \\
\hline Members Of Own Work Group & 88.8 & 247 \\
Others In Your Organization But Not & & \\
In Your Work Group & 89.7 & 245 \\
Others In Your Organization, Not In Your & & \\
Work Group, At A Geographically & & \\
Different Site & 77.5 & 210 \\
People Outside Your Work Group & 95.0 & 264 \\
\hline
\end{tabular}

\section{Use and Importance of Libraries/Technical Information Centers}

Almost all of the survey respondents indicated that their organization has a library/technical information center. About $23 \%$ of the survey respondents indicated that the library/technical information center was located in the building where they worked. About $73 \%$ of the respondents indicated that the library/technical information center was located outside the building in which they worked. Four percent of the respondents reported that their organization did not have a library/technical information center.

For $91 \%$ of the respondents, the library/technical information center was located 1 mile or less from where they worked. For about $9 \%$ of the respondents, the library/technical information center was located more than one mile from where they worked.

Survey respondents were also asked if the proximity of their work setting (i.e., distance from their office to their organization's library/technical information center) affected their use of that facility (table 27). The importance of proximity was measured on a 5-point scale with $1=$ not at all important and $5=$ very important. About $13 \%$ of the respondents indicated that proximity was "not at all" important. About $28 \%$ indicated that proximity was "neither important nor unimportant." Twenty-one percent of the respondents indicated that proximity was "very important." Overall, survey respondents were about equally divided on the extent to which proximity of the work setting to the library/technical information center influence its use.

Respondents were also asked to rate the importance of the organization's library/technical information center in terms of performing their professional duties. Importance was measured on a 5-point scale with $1=$ not at all important and $5=$ very important (see table 28). About $76 \%$ of the aerospace engineers and scientists in the study indicated that their organization's library/technical information center was important or very important in performing their present professional duties. Approximately $17 \%$ of the survey respondents indicated that their library was neither important nor unimportant to performing their present professional duties. About $7 \%$ of respondents indicated that their organization's library/technical information center was not at all important to performing their present professional duties. 
Table 27. The Influence of Proximity of the Organization's

Library/Technical Information Center on Use

\begin{tabular}{|l|c|c|}
\hline Proximity & Percentage & Number \\
\hline Unimportant & 24.3 & 71 \\
Neither Important Nor Unimportant & 27.7 & 81 \\
Important & 47.9 & 140 \\
\hline Mean & & \\
Median & 3.3 & \\
\hline
\end{tabular}

Table 28. Importance of the Organization's Library/Technical Information Center to Performance of Present Professional Duties

\begin{tabular}{|l|c|c|}
\hline Importance & Percentage & Number \\
\hline Unimportant & 7.2 & 21 \\
Neither Important Nor Unimportant & 16.8 & 49 \\
Important & 75.9 & 221 \\
\hline Mean & & \\
Median & \multicolumn{2}{|}{} \\
\hline
\end{tabular}

Survey respondents were asked the number of times they had used their organization's library in the past 6 months (table 29). Survey respondents used their library/technical information center about 16 times in the past 6 months. About $6 \%$ of the survey respondents did not use their organization's library in the past 6 months. Reasons for not using the organization's library

Table 29. Use of the Organization's Library/Technical Information Center in the Past 6 Months

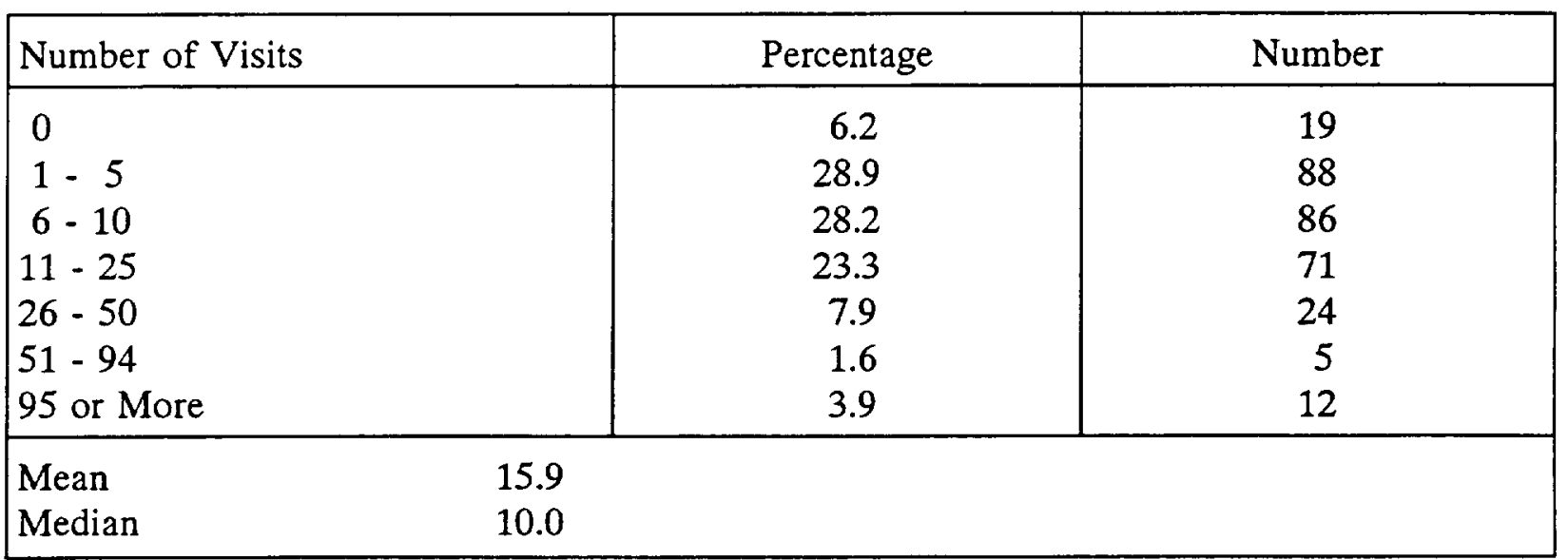


are shown in table 30 . About $94 \%$ of the respondents' information needs were more easily met some other way. About $46 \%$ indicated that the library was too slow in getting the information they needed. About $33 \%$ indicated that the library did not have the information they needed.

Table 30. Reasons Respondents Did Not Use A Library During the Past 6 Months

\begin{tabular}{|l|c|c|}
\hline Reason & Percentage & Number \\
\hline I Had No Information Needs & 26.7 & 4 \\
My Information Needs Were More Easily Met & 93.8 & 15 \\
$\quad$ Some Other Way & 15.4 & 2 \\
Tried The Library Once Or Twice Before But I & 0.0 & 0 \\
$\quad$ Couldn't Find The Information I Needed & 7.7 & 1 \\
The Library Staff Is Not Cooperative Or Helpful & 33.3 & 4 \\
The Library Staff Does Not Understand My & 21.4 & 3 \\
Information Needs & & \\
The Library Did Not Have The Information I Need & 46.2 & 6 \\
I Have My Own Personal Library And Do Not & 0.0 & 0 \\
Need Another Library & 7.7 & 1 \\
The Library Is Too Slow In Getting The & & \\
Information I Need & & \\
We Have To Pay To Use The Library & & \\
We Are Discouraged From Using The Library & & \\
\hline
\end{tabular}

\section{FINDINGS}

Readers should note that the data contained in this report reflect the responses of U.S. aerospace engineers and scientists who were members of the AIAA and were identified as educators. The results are not generalizable to (1) all U.S. aerospace engineers and scientists who are members of the AIAA or other professional societies, (2) all U.S. aerospace engineers and scientists, or (3) aerospace engineers and scientists employed outside of the U.S.

1. The "average" participant works in academia (100\%), has a doctorate (92.0\%), has an average of 22.3 years of work experience in aerospace, was educated as and works as an engineer $(83.9 \% / 63.5 \%)$, works in research $(74.8 \%)$, and is male $(95 \%)$.

2. Their most important job-related project, task, or problem worked on in the past 6 months was categorized as research (74.8\%); $75.6 \%$ of the participants worked on this project, task, or problem with others. The mean number of groups involved was 2.6 , and the mean number of people in a work group was 4.4. Engineering duties predominated (65.0\%) followed by science duties $(18.6 \%)$ in the completion of the most important job-related project, task, or problem worked on in the past 6 months. 
3. A positive and significant correlation was found between the overall complexity and technical uncertainty of the most important job-related project, task, or problem that respondents had worked on in the past 6 months.

4. To complete their most important job-related project, task, or problem, respondents first went to their personal stores of technical information (69.7\%); next, spoke with coworker(s) inside the organization (32.5\%), third and fourth, spoke with colleagues outside of the organization $(26.9 \% / 17.7 \%)$, and fifth, used literature resources in the organization's library (13.8\%). About $58 \%$ and $23 \%$, respectively, did not speak to a librarian or search (or have searched) electronic data bases to complete their most important job-related project, task, or problem.

5. Approximately $85 \%$ of the respondents reported using the results of federally funded aerospace R\&D in their work. Of the six sources most frequently used to find out about the results of federally funded aerospace $R \& D$, three involve interpersonal communication and three involve formal communication. Of the five "federal initiatives," NASA and DoD technical reports were used most often to learn about the results of federally funded aerospace R\&D.

6. About $84 \%$ of the respondents had used the results of federally funded aerospace R\&D to complete their most important job-related project, task, or problem during the last 6 months. About $80 \%$ of this group indicated that federally funded aerospace R\&D was "important" or "very important" for completing this work. About 68\% (156 respondents) of those who used the results of federally funded aerospace $R \& D$ in completing their most important job-related project, task, or problem indicated that the results were published in either a NASA or DoD technical report.

7. Of the respondents who used the results of federally funded aerospace R\&D in completing their most important job-related project, task, or problem, $61.1 \%$ indicated that the "time and effort it took to locate the results" was a problem, and $63.2 \%$ reported that the "time and effort it took to obtain the results" was a problem.

8. About $90 \%$ of the respondents indicated that it was important to communicate technical information effectively; respondents spent an average of 12.1 hours per week producing written material and 11.6 hours per week communicating information orally. Over the past 5 years approximately 53\% have increased the amount of time they spend communicating information to others. Survey respondents reported spending an average of 9.4 hours per week working with written information received from others and an average of 5.0 hours per week working with information received orally from others. About 57\% of the respondents indicated that the amount of time they spend working with technical information received from others has increased as they have advanced professionally.

9. About $16 \%$ of the respondents reported that all of the written technical communications they prepared involved writing alone. About $72 \%$ indicated that their written technical communications involved writing with one other person. About $54 \%$ indicated that their written technical 
communications involved writing with a group of two to five people. About $10 \%$ indicated that their written technical communications involved writing with a group of more than five people.

10. In terms of the perceived productivity of collaborative writing, slightly more of the respondents indicated that writing with a group is more productive than writing alone. About $35 \%$ indicated that a group is more productive and about $32 \%$ indicated that a group is less productive. About $34 \%$ indicated that a group is about as productive as writing alone.

11. A comparison of the technical information products produced and used reveals that on average, the survey respondents used more products than they produce. There are also slight differences in the types of technical information products produced and used.

12. Survey respondents were asked to indicate their use of and the importance to them of five technical information products. Journal articles were used most frequently $(\bar{X}=20.6)$ and, along with conference/meeting papers, were rated most important $(\bar{X}=4.5 / 4.2)$. DoD and NASA technical reports were used by about $56 \%$ and $81 \%$ of the respondents and the mean importance ratings were 2.8 and 3.4 , respectively.

13. Both users and non-users of the five information products were asked to indicate about the importance of eight factors in deciding whether to use any of the five information products. Overall, the factors exerting the greatest influence on decisions to use products follow.

Conference/meeting papers -- (1) relevant to my work, (2) good technical quality, (3) comprehensive data and information, (4) easy to physically obtain, and (5) easy to use or read.

Journal articles -- (1) relevant to my work, (2) good technical quality, (3) comprehensive data and information, (4) easy to physically obtain, and (5) easy to use or read.

In-house technical reports -- (1) relevant to my work, (2) good technical quality, (3) comprehensive data and information, (4) easy to physically obtain, and (5) easy to use or read.

DoD technical reports -- (1) relevant to my work, (2) good technical quality, (3) comprehensive data and information, (4) easy to physically obtain, and (5) easy to use or read.

NASA technical reports -- (1) relevant to my work, (2) good technical quality, (3) comprehensive data and information, (4) easy to physically obtain, and (5) easy to use or read.

14. About $98 \%$ of the survey participants used computer technology to prepare written technical communications; about $98 \%$ of them indicated that computer technology had increased their ability to communicate technical information.

15. Word processing and spelling checkers were the computer software used most often in preparing written technical information. 
16. FAX or TELEX, electronic mail, electronic networks, video conferencing, and electronic data bases were used most frequently by survey respondents.

17. About $77 \%$ of the survey participants used electronic (computer) networks in performing their present professional duties; they use electronic networks an average of 10.9 hours per week; and about $83 \%$ rated them important in terms of performing their present professional duties.

18. About $78 \%$ of the respondents access electronic (computer) networks via personal computer; about $99 \%$ use electronic (computer) networks for electronic mail.

19. About $76 \%$ of survey respondents indicated that the organization's library/technical information center was important in performing their present professional duties.

20. On average, survey respondents visited their organization's library/technical information center 16.9 times in a 6 month period; about $48 \%$ of survey respondents indicated that the proximity of the work setting to the organization's library/technical information center did influence its use.

21. The most common reasons for not using the organization's library/technical information center included "my information needs were more easily met some other way," "the library was too slow getting the information I needed," and "the library did not have the information I needed."

\section{REFERENCES}

Adam, R. 1975
"Pulling the Minds of Social Scientists Together: Towards a Science Information System." International Social Journal 27(3): 519-531. 
Allen, T. J. 1977

Auger, C. P. 1975

Ballard, S., et. al. 1989

Ballard, S., et. al. 1986

Berul, L. H., et. al. 1965

Beyer, J. M.

and H.M. Trice

1982

Bikson, T. K.,

B. E. Quint, and

L. L. Johnson

1984

Branscomb, L. G.

1992

Branscomb, L. G.

1991

David, P. A.

1986
Managing the Flow of Technology: Technology Transfer and the Dissemination of Technological Information Within the R\&D Organization. Cambridge, MA: MIT Press.

Use of Technical Reports Literature. Hamden, CT: Archon Books.

Innovation Through Technical and Scientific Information: Government and Industry Cooperation. Westport, CT: Quorum Books.

Improving the Transfer and Use of Scientific and Technical Information. The Federal Role: Volume 2 - Problems and Issues in the Transfer and Use of STI. Washington, DC: National Science Foundation. (Available from NTIS, Springfield, VA; PB87-14923.)

DoD User-Needs Study, Phase 1. Volume 1: Management Report, Conduct of the Study, and Analysis of Data. Philadelphia, PA: Auerbach Corporation. (Available from NTIS, Springfield, VA; AD-615 501.

"The Utilization Process: A Conceptual Framework and Synthesis of Empirical Findings." Administrative Science Quarterly 27: 591-622.

Scientific and Technical Information Transfer: Issues and Option. Washington, DC: National Science Foundation. (Available from NTIS, Springfield, VA; PB-85-150357; also available as Rand Note 2131.)

"America's Emerging Technology Policy." Minerva 30:3 (August): 317-336.

"Toward a U.S. Technology Policy." Issues in Science and Technology 7:4 (Fall): 50-55.

"Technology Diffusion, Public Policy, and Industrial Competitiveness." In The Positive Sum Strategy: Harnessing Technology for Economic Growth. R. Landau and N. Rosenberg, eds. Washington, DC: National Academy Press. 
Eveland, J. D.

1987

Flanagan, J. C.

1954

Fry, B. M.

1953

Gibb, J. M. and

E. Phillips

1979

Godfrey, L. E. and

H.F. Redman

1973

Goldhor, R. S. and R. T. Lund

1983

Lancaster, F. W.

1978

Mathes, J. C. and D. W. Stevenson 1976

McClure, C. R. 1988

McGowan, R. P. and S. Loveless 1981

Mowery, D. C. 1983

Mowery, D. C. and N. Rosenberg 1979
Scientific and Technical Information Exchange: Issues and Findings. Washington, DC: National Science Foundation. (Not available from NTIS.)

"The Critical Incident Technique." Psychology Bulletin 51:4 (July): $327-358$.

Library Organization and Management of Technical Reports Literature. Washington, DC: The Catholic University of America Press.

"Better Fate for the Grey, or Non-Conventional, Literature." Journal of Communication Studies 1: 225-234.

Dictionary of Report Series Codes. (2nd ed.) NY: Special Libraries Association.

"University-to-Industry Advanced Technology Transfer: A Case Study." Research Policy 12: 121-152.

Critical Incident Techniques. Urbana IL: University of Illinois Graduate School of Library and Information Science.

Designing Technical Reports. Indianapolis, IN: Bobbs-Merill.

"The Federal Technical Report Literature: Research Needs and Issues." Government Information Quarterly. 5(1): 27-44.

"Strategies for Information Management: The Administrator's Perspective." Public Administration Review 41(3): 331-339.

"Economic Theory and Government Technology Policy." Policy Sciences 16: 27-43.

"The Influence of Market Demand Upon Innovation: A Critical Review of Some Recent Empirical Studies." Research Policy 8(2): 102-153. 
National Academy of Sciences -

National Academy of Engineering 1969

Pinelli, T. E. 1991(a)

Pinelli, T. E. 1991(b)

Pinelli, T. E., J. M. Kennedy, and R. O. Barclay 1991

Pinelli, T. E., J. M. Kennedy, R. O. Barclay, and T. F. White 1991

President's Special Assistant for Science and Technology 1962

Redman, H. F. 1965/1966

Roberts, E. B. and A. L. Frohman 1978

Rohde, Nancy F. 1986
Scientific and Technical Communication: A Pressing National Problem and Recommendations for Its Solution. Report by the Committee on Scientific and Technical Communication. Washington, DC: National Academy Sciences; AKA the SATCOM Report.

"The Information-Seeking Habits and Practices of Engineers." Science and Technology Libraries 11(3): 5-25.

The Relationship Between the Use of U.S. Government Technical Reports by U.S. Aerospace Engineers and Scientists and Selected Institutional and Sociometric Variables. Washington, DC: National Aeronautics and Space Administration. NASA TM102774, January. (Available from NTIS, Springfield, VA; N9118898.)

"The NASA/DoD Aerospace Knowledge diffusion Research Project." Government Information Quarterly 8(2): 219-233.

"Aerospace Knowledge Diffusion Research." World Aerospace Technology '91: The International Review of Aerospace Design and Development 1(1): 31-34.

Scientific and Technological Communication in the Government. Washington, DC: Government Printing Office; AKA the Crawford Report.

"Technical Reports: Problems and Predictions." Arizona Librarian 23: 11-17.

"Strategies for Improving Research Utilization." Technology Review 80 (March/April): 32-39.

"Information Needs." In Advances in Librarianship, Vol. 14. W. Simonton, ed. NY: Academic Press, 49-73. 
Ronco, P. G., et. al. 1964

Shuchman, H. L. 1981

Smith, R. S.

1981

Subramanyam, $\mathrm{K}$. 1981

U.S. Department of Defense 1964

Williams, F. and D. V. Gibson 1990
Characteristics of Technical Reports That Affect Reader Behavior: A Review of the Literature. Boston, MA: Tufts University, Institute for Psychological Research. (Available from NTIS, Springfield, VA PB-169 409.)

Information Transfer in Engineering. Glastonbury, CT: The Futures Group.

"Interaction Within the Technical Report Community." Science and Technology Libraries 1(4): 5-18.

Scientific and Technical Information Resources. NY: Marcel Dekker.

Glossary of Information Handling. Defense Logistics Agency, Defense Documentation Center. Cameron Station, Alexandria, VA.

Technology Transfer: A Communication Perspective. Newbury Park, CA: Sage Publications. 


\title{
APPENDIX A: PROJECT FACT SHEET
}

\section{NASA/DoD AEROSPACE KNOWLEDGE DIFFUSION RESEARCH PROJECT}

\author{
Fact Sheet
}

The process of producing, transferring, and using scientific and technical information (STI), which is an essential part of aerospace research and development (R\&D), can be defined as Aerospace Knowledge Diffusion. Studies tell us that timely access to STI can increase productivity and innovation and help aerospace engineers and scientists maintain and improve their professional skills. These same studies indicate, however, that we know little about aerospace knowledge diffusion or about how aerospace engineers and scientists find and use STI. To learn more about this process, we have organized a research project to study knowledge diffusion. Sponsored by NASA and the Department of Defense (DoD), the NASA/DoD Aerospace Knowledge Diffusion Research Project is being conducted by researchers at the NASA Langley Research Center, the Indiana University Center for Survey Research, and Rensselaer Polytechnic Institute. This research is endorsed by several aero- space professional societies including the AIAA, RAeS, and DGLR and has been sanctioned by the AGARD and AlAA Technical Information Panels.

This 4-phase project is providing descriptive and analytical data about the flow of STI at the individual, organizational, national, and international levels. It is examining both the channels used to communicate STI and the social system of the aerospace knowledge diffusion process. Phase 1 investigates the information-seeking habits and practices of U.S. aerospace engineers and scientists, in particular their use of government-funded aerospace STI. Phase 2 examines the industry-government interface and emphasizes the role of the information intermediary in the knowledge diffusion process. Phase 3 concerns the academic-government interface and emphasizes the information intermediaryfaculty-student interface. Phase 4 explores the information-seeking behaviors of non-U.S. aerospace engineers and scientists from Western European nations, India, Israel, Japan, and the former Soviet Union.

The results of this research project will help us to understand the flow of STI at the individual, organizational, national, and international levels. The findings can be used to identify and correct deficiencies; to improve access and use; to plan new aerospace STI systems; and should provide useful information to R\&D managers, information managers, and others concerned with improving access to and utilization of STI. These results will contribute to increasing productivity and to improving and maintaining the professional competence of aerospace engineers and scientists. The results of our research are being shared freely with those who participate in the study.

Dr. Thomas E. Pinelli

Mail Stop 180A

NASA Langley Research Center

Hampton, VA 23681-0001

(804) 864-2491

Fax (804) 864-8311

T.E.Pinelli@larc.nasa.gov
Dr. John M. Kennedy Center for Survey Research

Indiana University

Bloomington, IN 47405

(812) 855-2573

Fax (812) 855-2818

kennedyJ@indiana.edu
Rebecca O. Barclay

Knowledge Transfer International

462 Washington Street

Portsmouth, VA 23704

(804) 397-4644

Fax (804) 397-4635

barclay@infi.net 


\title{
APPENDIX B: SURVEY INSTRUMENT
}

\author{
PHASE 1 OF THE \\ NASA/DOD AEROSPACE KNOWLEDGE \\ DIFFUSION RESEARCH PROJECT
}

\section{Technical Communications in Aerospace: The U.S. Aerospace Engineering Faculty Perspective}

The American institute of Aeronautics and Astronautics Survey
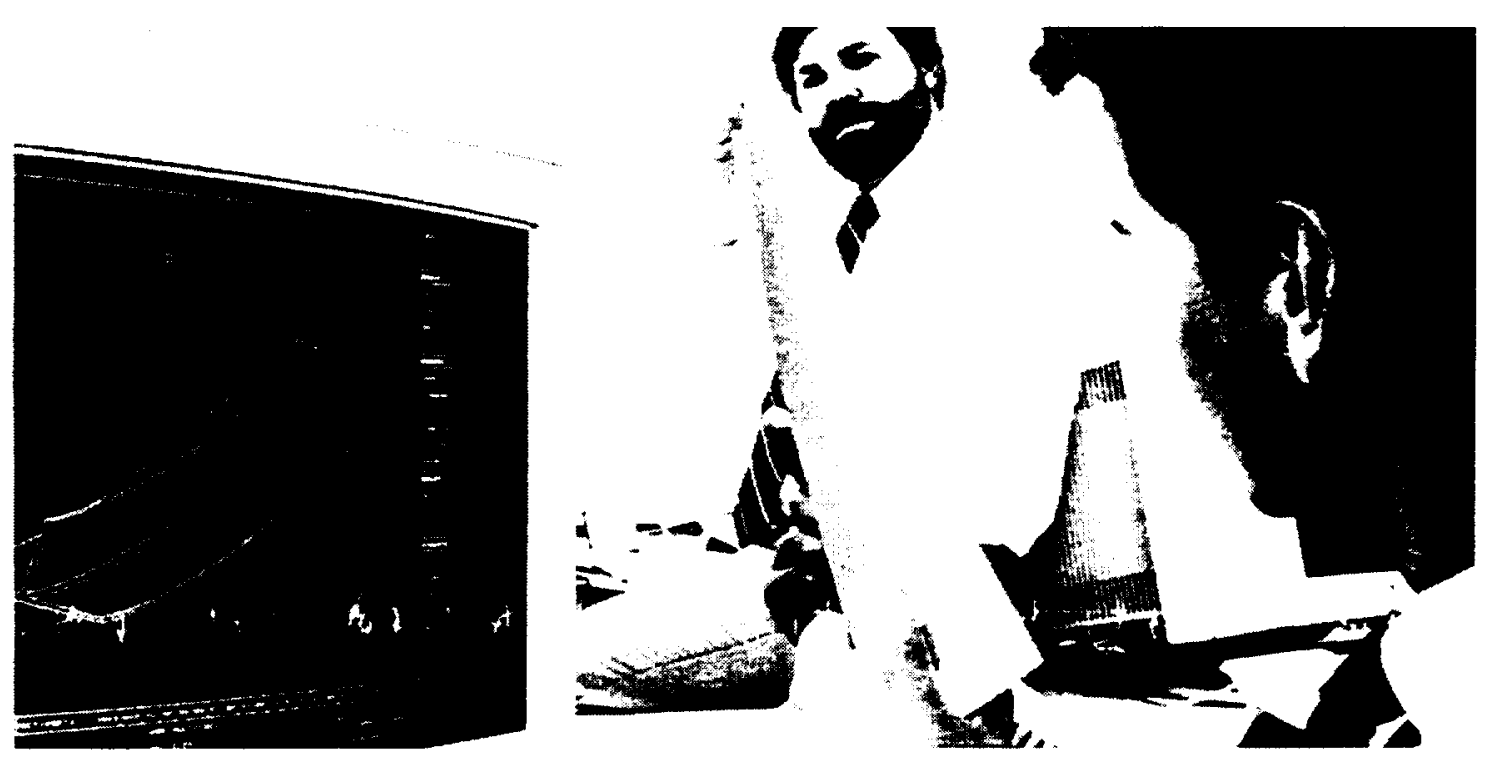

SPONSORED BY THE NATIONAL AERONAUTICS AND SPACE ADMINISTRATION AND THE DEPARTMENT OF DEFENSE WITH THE COOPERATION OF INDIANA UNIVERSITY 
The first group of questions ask about your we of technical information.

1. In your work, how important is it for you to cammuoricate (eg., produce written materials or onl discussions) technical information effectively? (Circle number)

$\begin{array}{lllllll}\text { Not at all important } & 1 & 2 & 3 & 4 & 5 & \text { Very Important }\end{array}$

2 In the past 6 months, about bow many bours did you spend each week communicating (producing) technical information?

(Output)

hours per week writing

hours per week communicating orally

3. Compared to 5 years ago, how has the amount of time you spend communicating technical information changed? (Circle ONE number)

$\begin{array}{ll}1 & \text { Increased } \\ 2 & \text { Stayed the same } \\ 3 & \text { Decreased }\end{array}$

4. In the past 6 months, about bow many hours did you spend each week working with tochnical information received from others?

(Input) hours per week working with written information bours per week receiving information orally

5. As you have advanced professionally, how has the amount of time you spend working with technical information received from others changed? (Circle ONE number)

$\begin{array}{ll}1 & \text { Increased } \\ 2 & \text { Snyed the same } \\ 3 & \text { Decreased }\end{array}$

6. In the past 6 months, about what percentage of your written technical communications involved:

Writing alome

Writing with one other person

Writing with a group of 2 to 5 people

Writing with a group of more than 5 people

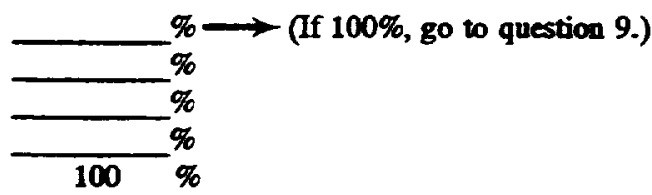

7. In general, do you find writing as part of a group more or less productive (Le, producing more written products or better written products) than writing alone? (Circle ONE number)

1 A group is less productive than writing alone

2 A group is about as productive as writing alone

3 A group is more productive than writing alone

4 Difficult to judge; no experience preparing technical information

8. In the past 6 months, did you work with the same group of people when producing written technical information? (Circle ONE number)

1 Yes $\longrightarrow$ About how many people were in the group? number of people

2 No $\longrightarrow$ With about bow many groups did you work? number of groups<smiles>C[Te]</smiles>

About how many people were in each group? number of people 
9. Approximately bow many times in the past 6 months did you write or prepare the following alone or in a group? (If in a group, how many people were in cach group?)

Times Wrote or Prepared in Past 6 Months

2. Abstracts

b. Journal Articles

c. Conference/Meeting Papers

d. Trade/Promotional Literature

e. Drawings/Specifications

f Audio/Visual Materials

g. Letters

h. Memoranda

i Technical Proposals

j. Technical Manmals

k. Computer Program Documentation

1. In-house Technical Reports

I. DoD Technical Report:

u. NASA Technial Reports

o. Technical Talks/Presentutions

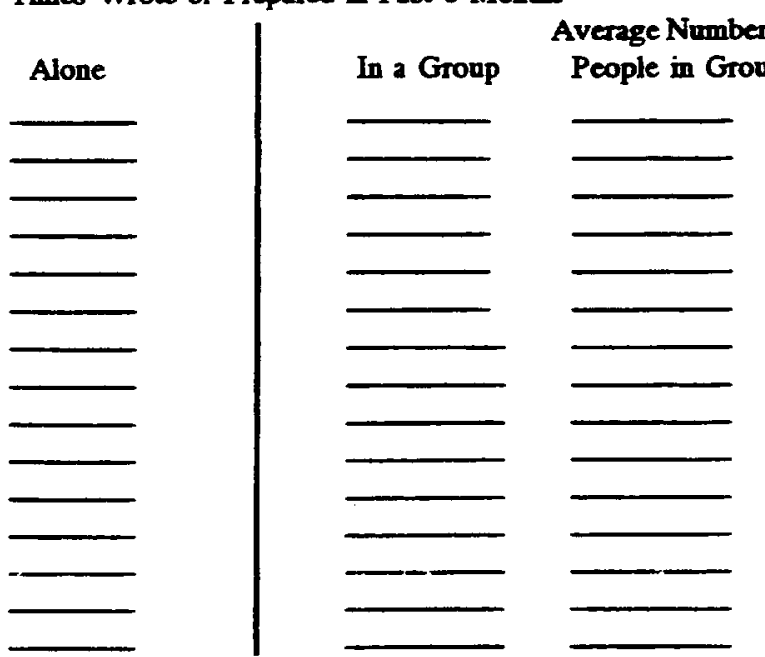

10. Approximately how many times in the past 6 months did you use the following as part of your professional duties?

Times Used in Past 6 Months
a. Abstracts
b. Joumal Articies
c. Conference/Meeting Papers
d. Trade/Promotional Literature
c Drawings/Specifications
f Audio/Visual Materials
g. Letters
h. Memoranda
i. Technical Proposals
j. Technical Manuals
k. Computer Program Documentation
1 In-house Technical Reports
m. DoD Technical Reports
n. NASA Technical Reports
o. Technical Talks/Presentations

Nert, a few questions about computer use.

11. Do you use computer tochnology to prepare technical information? (Circle ONE number)

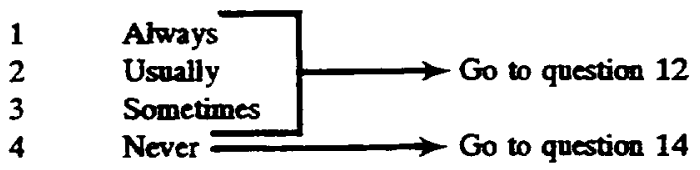

12 Has computer technology increased your ability to communicate technical information? (Circle ONE number)

$\begin{array}{ll}1 & \text { Yes, a lot } \\ 2 & \text { Yes, a little } \\ 3 & \text { No }\end{array}$


13. Do you use any of the following software to prepare written technical information? (Circle the appropriate number for each)

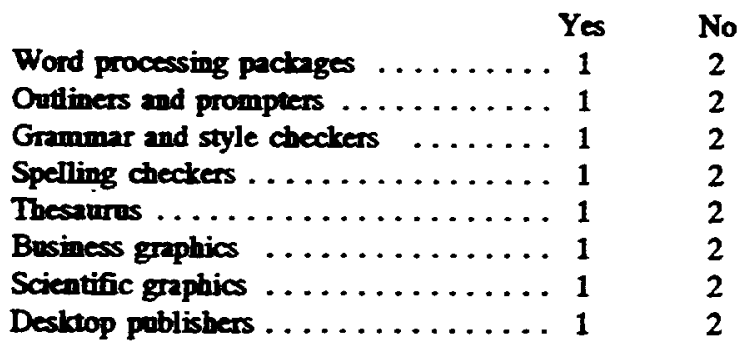

14. How do you view your USE of the following electronicfinformation technologies in commmiating technical information? (Circle the approprinte number for each)

$\begin{array}{cccc} & \text { Don't use } & \text { Don't use } \\ \text { Information Technologies } & \text { Already } & \text { bot may in } & \text { and doubt } \\ \text { Use } & \text { the future } & \text { if I will }\end{array}$

Audio upes and cassettes ......... 1

Motion picture films ........... 1

Video tope ............... 1

Desktop/electronic publishing ....... 1

Computer cassette/cartridge tapes .... 1

Electronic mail ............. 1

Electronic bulletin boards .......... 1

FAX or TELEX ............ 1

Electronic data bases ........... 1

Video conferencing ........... 1

Micrographics and microforms ...... 1

Laser disc/video disc/CD-ROM . . . . . 1

Electronic networks ............ 1

No
2
2
2
2
2
2

At your workplace, do you nse electronic networks in performing your present duties? (Circle ONE number)

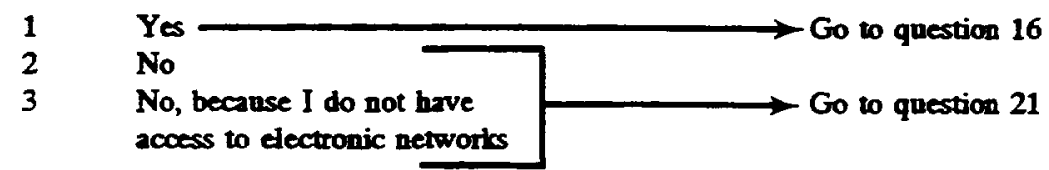

16. At your workplace, bow do you access electronic networks? (Circle all that apply)

$\begin{array}{ll}1 & \text { By using a mainframe terminal } \\ 2 & \text { By using a personal computer } \\ 3 & \text { By using a workstation }\end{array}$

17. How important is the use of electronic networks in performing your present duties? (Circle number)

$\begin{array}{llllllll}\text { Not at all importnt } & 1 & 2 & 3 & 4 & 5 & \text { Very Important }\end{array}$

18. In the past week, about how many hours did you USE your electronic networks?

Hours in the past week 
19. Do you use electronic networks for the following purposes? (Circle appropriate number for each)

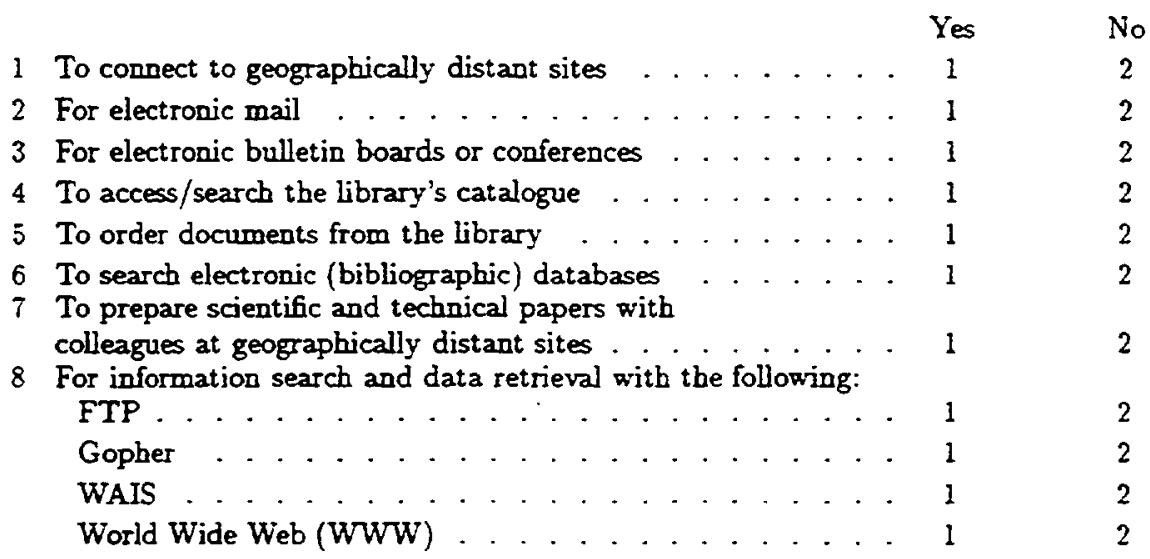

20. Do you USE clectronic networks to communicate with:

Members of your work group $\ldots \ldots \ldots \ldots \ldots \ldots \ldots \ldots \ldots$
Other people in your organization at the SAME geographical
site who are NOT in your work group $\ldots \ldots \ldots \ldots \ldots \ldots \ldots \ldots \ldots$

We would also like to know about your use of a library or technical information center.

21. Does your organization/company have a library/hechnical information center? (Circle ONE number)

$1 \quad$ Yes, in my building $\longrightarrow$ Go to question 22
$2 \quad$ Yes, but not in my building
$3 \quad$ No $\longrightarrow$ Go to question 26

22 In the past 6 months, how often did you USE your organization's library/technical information center?

Number of times in past 6 months

If "0" times or you did not use your organizntion's bbrary, go to question 25.

23. To what extent does the proximity of your work setting (eg., office) to your organization's library/technical information center affect your use of it? (Circle ONE number)

$\begin{array}{llllllll}\text { Not at all important } & 1 & 2 & 3 & 4 & 5 & \text { Very Important }\end{array}$

24. In terms of performing your present professional duties, how important is your organization's libraryhechnical information center? (Circle ONE number)

$\begin{array}{lllllll}\text { Not at all important } & 1 & 2 & 3 & 4 & 5 & \text { Very Important }>\text { Go to question } 26\end{array}$ 
25. Which of the following statements describe your reasons for not using a library during the past 6 months? (Circle appropriate number for each)

$$
\text { Yes No }
$$

I had no information needs $\ldots \ldots \ldots \ldots \ldots \ldots \ldots \ldots \ldots \ldots \ldots \ldots \ldots$

My information needs were more easily met some other way ........ 1

Tried the library once or twice before but I couldn't

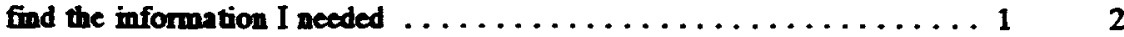

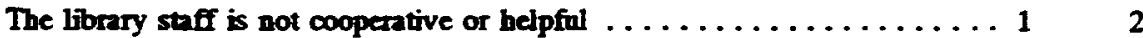

The library staff does not understand my information needs ......... 1 2

The library did not have the information I needed $\ldots \ldots \ldots \ldots \ldots \ldots \ldots 1$

The library is too slow in getting the information I need $\ldots \ldots \ldots \ldots \ldots 1$. 2

I have my own personal library and do not need another library ........ 1

We have to pay to use the library $\ldots \ldots \ldots \ldots \ldots \ldots \ldots \ldots \ldots \ldots \ldots$. 2

We are discouraged from using the library $\ldots \ldots \ldots \ldots \ldots \ldots \ldots \ldots \ldots$

Please tell us about your use of specific information products.

26. Do you use the following information products in performing your present professional duties?

(Circle appropriate number for each)

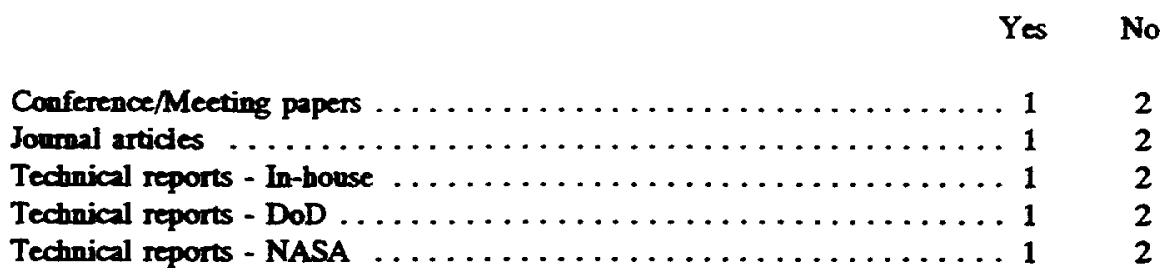

27. In terms of performing your present professional duties, how important is each of the following information sources? (Circle appropriate number for each)

Not at all

Very

Important

Important

\begin{tabular}{|c|c|c|c|}
\hline Conference/Meeting papers $\ldots \ldots \ldots \ldots \ldots \ldots \ldots$ & 2 & 3 & 4 \\
\hline Journal articles $\ldots . . .$. & 2 & 3 & 4 \\
\hline Technical reports - In-house $\ldots \ldots \ldots \ldots \ldots \ldots$ & 2 & 3 & 4 \\
\hline Technical reports - DoD $\ldots \ldots \ldots \ldots \ldots \ldots \ldots$ & 2 & 3 & 4 \\
\hline Technical reports - NASA $\ldots \ldots \ldots$ & 2 & 3 & 4 \\
\hline
\end{tabular}

28. If you were deciding whether or not to use conference/neeting papers in your work, how important would the following factors be? (Circle appropriate number)

Not at all

Very

Important

Important

Are easy to physically obtin $\ldots \ldots \ldots \ldots \ldots \ldots$

Are easy to use or read $\ldots \ldots \ldots \ldots \ldots \ldots \ldots \ldots$

Are inexpensive $\ldots \ldots \ldots \ldots \ldots \ldots \ldots \ldots \ldots$

Have good technical quality $\ldots \ldots \ldots \ldots \ldots \ldots \ldots \ldots 1$

Hrve comprehensive data and information ........

Are relevant to my work $\ldots \ldots \ldots \ldots \ldots \ldots \ldots \ldots$

Can be obmined at a nearby location or source $\ldots \ldots \ldots \ldots 1$

Had good prior experience using them . . . . . . . . 1

$\begin{array}{llll}2 & 3 & 4 & 5 \\ 2 & 3 & 4 & 5 \\ 2 & 3 & 4 & 5 \\ 2 & 3 & 4 & 5 \\ 2 & 3 & 4 & 5 \\ 2 & 3 & 4 & 5 \\ 2 & 3 & 4 & 5 \\ 2 & 3 & 4 & 5\end{array}$


32 If you were deciding whether or not to use NASA technical reports in your work, how important would the following factors be? (Circle appropriate number)

Not at all

Important

Are easy to physically obtzin $\ldots \ldots \ldots \ldots \ldots \ldots 1$

Are easy to use or read $\ldots \ldots \ldots \ldots \ldots \ldots \ldots 1$

Are inexpensive . . . . . . . . . . . . . . 1

Have good tochnical quality $\ldots \ldots \ldots \ldots \ldots \ldots \ldots 1$

Have comprebensive data and information ........

Are rejevant to my work ................ 1

Can be obtained at a nearby location or source $\ldots \ldots \ldots 1$

Had good prior experience using them ..........
Very

Important

33. (Even if you don't use them...) What is your opinion of conference or meeting papers? (Circle Number)

They are easy to physically obtair $\quad \begin{array}{llllll}1 & 2 & 3 & 4 & 5 & \text { They are difficult to physically obtain }\end{array}$

They are easy to use or read

They are inexpensive

$\begin{array}{llllll}1 & 2 & 3 & 4 & 5 & \text { They are difficolt to use or read }\end{array}$

They are of good tectnical quality

$\begin{array}{llllll}1 & 2 & 3 & 4 & 5 & \text { They are expensive }\end{array}$

They have comprehensive dat

and information

They are relevant to my work

They can be obtained at a

nearby location or source

I've had good prior experiences

using them

$\begin{array}{lllll}1 & 2 & 3 & 4 & 5\end{array}$ They are of poor technical quality

They have incomplete dat

$\begin{array}{lllll}1 & 2 & 3 & 4 & 5\end{array}$ and information

$\begin{array}{lllll}1 & 2 & 3 & 4 & 5\end{array}$ They are irrelevant to my work

They must be obtained from a

$\begin{array}{lllll}1 & 2 & 3 & 4 & 5\end{array}$ distant location or source

123 I've had bad prior experiences

using them

34. (Even if you don't use them...) What is your opinion of journal articles? (Circle Number)

They are easy to physically obtain $\begin{array}{lllllll}1 & 2 & 3 & 4 & 5 & \text { They are difficult to physically obtain }\end{array}$

They are easy to use or read

They are inexpensive

123

45 They are difficalt to use or read

They are of good technical quality

123

They have comprehensive data

and information

They are relevant to my work

They can be obtained at a

nearby location or source

I've had good prior experiences

using them

$\begin{array}{lllll}1 & 2 & 3 & 4 & 5\end{array}$

5 They are expensive

5 They are of poor technical quality

They have incomplete data

$\begin{array}{llllll}1 & 2 & 3 & 4 & 5 & \text { and information }\end{array}$

$\begin{array}{llllll}1 & 2 & 3 & 4 & 5 & \text { They are irrelevant to my work }\end{array}$

$\begin{array}{llllll} & 2 & 3 & 4 & 5 & \text { distant location or source }\end{array}$

12 I've had bad prior experiences 
35. (Even if you don't use them..) What is your opinion of in-house technical reports? (Circle Number)

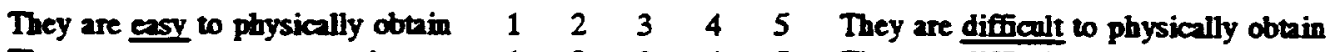

They are easy to use or read

They are inexpensive

They are of good technical quality

They have comprebensive dat and information

They are relevant to my work

They can be obtained at a nearby location or source I've had good prior experiences nsing them

123

123

$\begin{array}{lll}1 & 2 & 3\end{array}$

45 They are dificicult to use or read

45 They are expensive

45 They are of poor technical quality

$\begin{array}{lllll}1 & 2 & 3 & 4 & 5\end{array}$ and information

$\begin{array}{llllll}1 & 2 & 3 & 4 & 5 & \text { They are irrelevant to my work }\end{array}$

They must be obtained from a

$\begin{array}{lllll}1 & 2 & 3 & 4 & 5\end{array}$ distant location or source

$\begin{array}{llllll}1 & 2 & 3 & 4 & 5 & \text { using them }\end{array}$

36. (Even if you don't use them..) What is your opinion of DoD technical reports? (Circle Number)

They are easy to physically obtin $\begin{array}{llllll}1 & 2 & 3 & 4 & 5\end{array}$ $\begin{array}{llllll}\text { They are easy to use or read } & 1 & 2 & 3 & 4 & 5\end{array}$ They are inexpensive They are of good technical quality They have comprehensive dat and information

They are relevant to my work They can be obtined at a neaby location or source I've bad good prior experiences using them

$\begin{array}{lllll}1 & 2 & 3 & 4 & 5 \\ 1 & 2 & 3 & 4 & 5\end{array}$

$\begin{array}{lllll}1 & 2 & 3 & 4 & 5\end{array}$

$\begin{array}{lllll}1 & 2 & 3 & 4 & 5\end{array}$

$\begin{array}{lllll}1 & 2 & 3 & 4 & 5\end{array}$

$\begin{array}{lllll}1 & 2 & 3 & 4 & 5\end{array}$

$\begin{array}{lllll}1 & 2 & 3 & 4 & 5\end{array}$
They are difficuit to physically obtain They are difficuit to ase or read They are expensive They are of poor technical quality They have incomplete dat and information They are irrelevant to my work They must be obtained from a distant location or source I've had bad prior experiences using them

37. (Even if you don't use them...) What is your opinion of NASA technical reports? (Circle Number)

They are easy to physically obmin They are easy to use or read They are inexpensive

They are of good technical quality They have compreheasive dat and information

They are relevant to my work They can be obtained at a nearby location or source I've had good prior experiences using them

$\begin{array}{llll}1 & 2 & 3 & 4 \\ 1 & 2 & 3 & 4 \\ 1 & 2 & 3 & 4 \\ 1 & 2 & 3 & 4 \\ 1 & 2 & 3 & 4 \\ 1 & 2 & 3 & 4 \\ 1 & 2 & 3 & 4 \\ 1 & 2 & 3 & 4\end{array}$

They are difficult to physically obtin They are difficult to nse or read They are expensive They are of poor tochnical quality They have incomplete dat and information They are irrelevant to my work They must be obtained from a distant location or source I've had bad prior experiences using them 
Nert, we wonld Fike to know sbout the work you da.

38. Think of the most important job-related project, task, or problem you have worked on in the past 6 months. Which category best describes this work? (Circle only ONE number)

1 Research (either basic or applied)

2 Design/Development

3 Manufacturing/Production

4 Quality Assurance/Control

$5 \quad$ Computer Applications

6 Mmagement (c.g, planning, budgeting, and managing research)

7 Other (specify):

39. How would you describe the overall complexity of the technical project, task, or problem you categorized in Question 38? (Circie ONE number)

$\begin{array}{lllllll}\text { Very Simple } & 1 & 2 & 3 & 4 & 5 & \text { Very Complex }\end{array}$

40. How would you rate the amount of technical uncertainty that you faced when you started the technical project, task, or problem categorized in Question 38? (Circie ONE number)

$\begin{array}{lllllll}\text { Little Uncertainty } & 1 & 2 & 3 & 4 & 5 & \text { Great Uncertainty }\end{array}$

41. While you were involved in this technical project, task, or problem, did you work alone or with others?

$1 \quad$ Alone

2 With others $\longrightarrow$ In how many groups did you work?

About how many people were in each group?

42 Which one of the following best describes the kinds of duties you performed while working on the technical project, task, or problem categorized in Question 38? (Circle ONE number)

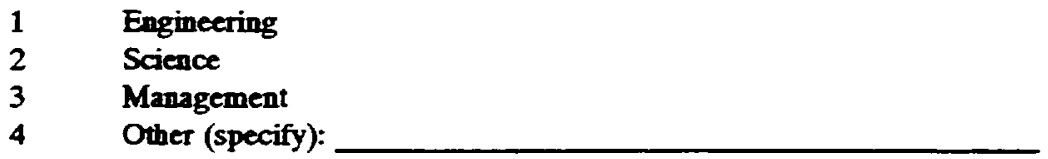

43. What steps did you follow to get the information you needed for this project, task, or problem? rPlease sequence these items (eg., \#1, \#2.\#3) and put an X beside the steps you did not use.]

Used my personal store of technical information, including sources I keep in my office Spoke with coworkers or people inside my organization Spoke with colleagues outside my organization Spoke with a librarian or technical information specialist Searched (or had someone search for me) an electronic (bibliographic) data base in the library Used literature resources (e.g., technical reports) found in my onganization's library

Used none of the above steps 
44. Do you USE the results of federally-funded aerospace R\&D in your work? (Circle ONE number)

1 Yes 2 No

45. Did you USE the results of federally-funded aerospace R\&D in completing the technical project, task, or problem you categorized in Question 38? (Circle ONE number)

1 Yes $2 \quad$ No $\longrightarrow$ Go to question 50

46. How important were the results of federally-funded R\&D in completing the technical project, task, or problem you categorized in Question 38? (Circle ONE number)

$\begin{array}{lllllll}\text { Not at all important } & 1 & 2 & 3 & 4 & 5 & \text { Very Important }\end{array}$

47. Were any of these results published in either a NASA or DoD tochnical report? (Circle ONE number)

1 Yes $\quad 2$ No

48. From which of the following sources did you leam about/obtain the results of the federally-funded aerospace R\&D you used in completing the technical project, task, or problem? (Circle appropriate number for each)

Yes No

Coworkers inside my organization ......... 1

Colleagues ontside my organization ........ 1

NASA and DoD contmats ............

Publications such as NASA STAR ... . . . . 1

NASA and DoD sponsored and co-

sponsored conferences and workshops $\ldots \ldots \ldots 1 \quad 2$

NASA and DoD tochnical reports $\ldots \ldots \ldots \ldots \ldots 1 \quad 2$

Professional and society journals . . . . . . . 1 2

Librarians inside my organizations . . . . . . . 1

Trade journals . . . . . . . . . . . . . . 1

Searches of computerized dat bases $\ldots \ldots \ldots \ldots 1 \quad 2$

Professional and society meetings $\ldots \ldots \ldots \ldots 12$

Visits to NASA and DoD facilities ........ 1

49. Which, if any, of the following problems were associated with using these results? (Check ALL that apply)

The time and effort it took to locate the results

The time and effort it took to physically obtain the results

The accuracy, precision, and reliability of the results

The legibility or readability of the results

The organization or format of the results

The distribution limitations or security restrictions of the results

Cver Piease $\longrightarrow$ 


\title{
Survey Demographics
}

50. Gender.
1. Female
2. Male

51. Highest college degree you hold:

1. Bachelor's

3. Doctorate

2. Master's

4. Other (Please Specify)

52. Your age:

53. Years of professional work experience in aerospace:

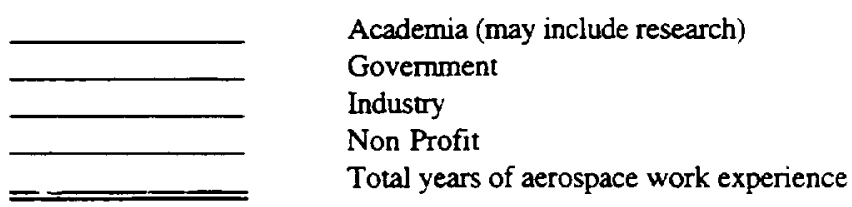

54. Was your academic preparation as an: (Circle ONLY one number)

1. Engineer

2. Scientist

3. Other (please specify):

55. In your present position, do you consider yourself primarily an: (Circle ONLY one number)

1. Engineer

2. Scientist

3. Other (please specify):

56. Is any of your current work funded by the (U.S.) federal government? (Circle ONLY one number)
1. Yes
2. No
3. Don't know

57. Tenured:
1. Yes
2. No
3. Not applicable

58. U.S. Citizen
1. Yes
2. No

59. Academic Rank (Circle ONLY one number)

1. Professor

3. Asst. Professor

2. Assoc. Professor

4. Other (please specify):

\section{THANK YOU!}

Mail to:

\author{
NASA/DoD Aerospace Knowledge Diffusion Research Project \\ NASA Langley Research Center \\ Mail Stop 180A \\ Hampton, VA 23681-0001
}




\begin{tabular}{|c|c|c|c|}
\hline \multicolumn{3}{|c|}{ REPORT DOCUMENTATION PAGE } & $\begin{array}{l}\text { Form Approved } \\
\text { OMB No. 0704-0188 }\end{array}$ \\
\hline \multicolumn{4}{|c|}{ 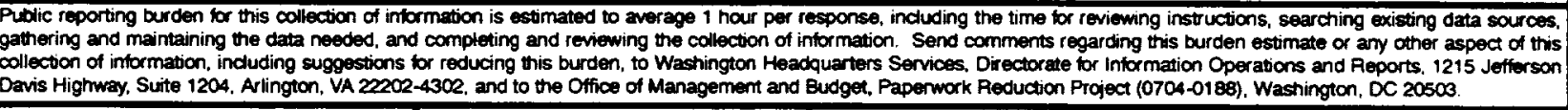 } \\
\hline 1. AGENCY USE ONLY (Leave blank) & $\begin{array}{l}\text { 2. REPORT DATE } \\
\text { July } 1996\end{array}$ & \multicolumn{2}{|c|}{$\begin{array}{l}\text { 3. REPOAT TYPE AND DATES COVERED } \\
\text { Technical Memorandum }\end{array}$} \\
\hline \multicolumn{3}{|c|}{$\begin{array}{l}\text { 4. TTLE AND SUBTTLE } \\
\text { The Technical Communications Practices of U.S. Aerospace Engineers } \\
\text { and Scientists: Results of the Phase } 3 \text { U.S. Aerospace Engineering } \\
\text { Educators Survey* }\end{array}$} & \multirow[t]{2}{*}{$\begin{array}{l}\text { 5. FUNDING NUMBERS } \\
\text { WU } 505-90\end{array}$} \\
\hline \multicolumn{3}{|c|}{$\begin{array}{l}\text { 6. AUTHOR(S) } \\
\text { Thomas E. Pinelli, Rebecca O. Barclay, and John M. Kennedy }\end{array}$} & \\
\hline \multicolumn{3}{|c|}{ 7. PERFOAMING ORGANIZATION NAME(S) AND ADDRESS(ES) } & $\begin{array}{l}\text { 8. PERFORMING ORGANIZATION } \\
\text { REPORT NUMBER }\end{array}$ \\
\hline \multicolumn{3}{|c|}{ 9. SPONSORING/MONITORING AGENCY NAME(S) AND ADDRESS(ES) } & $\begin{array}{l}\text { 10. SPONSOAINGMONITORING } \\
\text { AGENCY REPOAT NUMBER } \\
\text { NASA TM-110238 }\end{array}$ \\
\hline \multicolumn{4}{|c|}{$\begin{array}{l}\text { 11. SUPPLEMENTARY NOTES } \\
\text { *Report number } 45 \text { under the NASA/DoD Aerospace Knowledge Diffusion Research Project. Thomas E. Pinelli: } \\
\text { Langley Research Center, Hampton, VA; Rebecca O. Barclay: Knowledge Transfer International, Portsmouth, VA; } \\
\text { John M. Kennedy: Indiana University, Bloomington, IN. }\end{array}$} \\
\hline \multicolumn{2}{|c|}{$\begin{array}{l}\text { 12a. DISTRIBUTION/AVALABIUTY STATEMENT } \\
\text { Unclassified-Unlimited } \\
\text { Subject Category } 82\end{array}$} & 12b. DISTRI & 12b. DISTRIBUTION CODE \\
\hline \multicolumn{4}{|c|}{$\begin{array}{l}\text { 13. ABSTRACT (Maximum } 200 \text { words) } \\
\text { The U.S. government technical report is a primary means by which the results of federally funded research and } \\
\text { development (R\&D) are transferred to the U.S. aerospace industry. However, little is known about this information } \\
\text { product in terms of its actual use, importance, and value in the transfer of federally funded R\&D. To help establish } \\
\text { a body of knowledge, the U.S. government technical report is being investigated as part of the NASA/DoD Aero- } \\
\text { space Knowledge Diffusion Research Project. In this report, we summarize the literature on technical reports and } \\
\text { provide a model that depicts the transfer of federally funded aerospace R\&D via the U.S. government technical } \\
\text { report. We present results from our investigation of aerospace knowledge diffusion vis-á-vis the U.S. government } \\
\text { technical report, and present the results of research that investigated aerospace knowledge diffusion vis-á-vis the } \\
\text { technical communications practices of U.S. aerospace engineers and scientists who were members of the American } \\
\text { Institute of Aeronautics and Astronautics (AIAA) and identified themselves as educators. }\end{array}$} \\
\hline \multirow{2}{*}{\multicolumn{3}{|c|}{$\begin{array}{l}\text { 14. SUBJECT TERMS } \\
\text { Knowledge diffusion; Aerospace engineers and scientists; Information use; and U.S. } \\
\text { government technical reports }\end{array}$}} & $\begin{array}{l}\text { 15. NUMBER OF PAGES } \\
50\end{array}$ \\
\hline & & & $\begin{array}{r}\text { 16. PRICE CODE } \\
\text { A03 }\end{array}$ \\
\hline $\begin{array}{l}\text { 17. SECURITY CLASSIFICATION } \\
\text { OF REPORT } \\
\text { Unclassified }\end{array}$ & $\begin{array}{l}\text { 18. SECURITY CLASSIFICATION } \\
\text { OF THIS PAGE } \\
\text { Unclassified }\end{array}$ & $\begin{array}{l}\text { 19. SECURITY CLASSIFICATION } \\
\text { OF ABSTRACT } \\
\text { Unclassified }\end{array}$ & $\begin{array}{l}\text { 20. LMMTATION } \\
\text { OF ABSTRACT }\end{array}$ \\
\hline NSN 7540-01-280-5500 & & & $\begin{array}{l}\text { Standard Form } 298 \text { (Rev. 2-89) } \\
\text { Prescribed by ANSI Std. Z39-18 } \\
\text { 298-102 }\end{array}$ \\
\hline
\end{tabular}



